\title{
Rhönite in Cenozoic alkali basalt from Changle, Shandong Province, China, and its significance
}

\author{
Fan-Mei Kong ${ }^{1}$, Hans-Peter Schertl ${ }^{2,3}$, Ling-Quan Zhao ${ }^{2}$, Xu-Ping $\mathrm{Li}^{1}$, and Xiao-Han Liu ${ }^{1}$ \\ ${ }^{1}$ Shandong Provincial Key Laboratory of Depositional Mineralization \& Sedimentary Minerals, College of \\ Earth Science and Engineering, Shandong University of Science and Technology, Qingdao 266590, China \\ ${ }^{2}$ Faculty of Geosciences, Institute of Geology, Mineralogy and Geophysics, \\ Ruhr University Bochum, 44780 Bochum, Germany \\ ${ }^{3}$ College of Earth Science and Engineering, Shandong University of Science and Technology, \\ Qingdao 266590, China
}

Correspondence: Fan-Mei Kong (kongfanmei56@sdust.edu.cn, fmkongkfm@126.com)

Received: 25 March 2019 - Revised: 24 March 2020 - Accepted: 24 April 2020 - Published: 8 June 2020

\begin{abstract}
Four Cenozoic, rhönite-bearing alkali-olivine basalt samples from the Changle area (Shandong Province, China) show an intracontinental character and were generated in an extensional setting. Petrographic studies document different generations of rhönite. In three samples, rhönite occurs either as a reaction product surrounding coarse-grained corundum, spinel and phlogopite or along cleavage planes in phlogopite. In one sample rhönite forms disseminated crystals in a mantle xenolith, possibly formed by a reaction of coarsegrained orthopyroxene or spinel with a melt. Rhönite exhibits a wide range of compositions: $22.9 \mathrm{wt} \%-33.0 \mathrm{wt} \%$ $\mathrm{SiO}_{2}, 13.3 \mathrm{wt} \%-19.0 \mathrm{wt} \% \mathrm{Al}_{2} \mathrm{O}_{3}, 9.4 \mathrm{wt} \%-19.9 \mathrm{wt} \% \mathrm{MgO}$ and $10.210 .2 \mathrm{wt} \%-24.5 \mathrm{wt} \% \mathrm{FeO}$. The derived primary substitutions include (1) $\mathrm{Si}^{\mathrm{IV}}+\mathrm{Na}^{\mathrm{VII}}=\left(\mathrm{Al}, \mathrm{Fe}^{3+}\right)^{\mathrm{IV}}+\mathrm{Ca}^{\mathrm{VII}}$, (2) $\mathrm{Mg}^{\mathrm{VI}}=\left(\mathrm{Fe}^{2+}, \mathrm{Mn}^{2+}\right)^{\mathrm{VI}}$ and (3) $\mathrm{Ti}^{\mathrm{VI}}$ $+\left(\mathrm{Mg}+\mathrm{Fe}^{2+}+\mathrm{Mn}^{2+}\right)^{\mathrm{VI}}=2 \mathrm{Fe}^{3+\mathrm{VI}}$.

Rare-earth-element (REE) patterns of euhedral rhönite crystals from the mantle xenolith (sample SS17) and those surrounding spinel (sample CL04) have a concave-upward shape for the heavy rare-earth elements (HREEs) and are slightly enriched in the light rare-earth elements (LREEs). These patterns resemble those of kaersutitic amphibole and kaersutite reported from basanite, olivine nephelinite, transitional alkali-olivine basalt and hawaiite. In contrast, REE patterns of the other two samples containing fine-grained, anhedral and acicular rhönite crystals (samples CL01 and EGS03) are relatively steep, with lower HREE and higher LREE abundances, similar to those of ocean island basalts (OIBs). All types of Changle rhönite show positive $\mathrm{Nb}$, Ti and $\mathrm{V}$ anomalies in spidergrams normalized to primitive mantle.

Mineral assemblages of the studied samples indicate that rhönite crystallized at different stages within a temperature range from about 950 to $1180^{\circ} \mathrm{C}$ and at pressures below $0.5 \mathrm{kbar}$, with $f \mathrm{O}_{2}$ below the NNO buffer. The chemical composition of Changle rhönite is interpreted to depend on the composition of the initial silicate melt, the redox conditions during crystallization and the composition of the minerals involved in reactions to form rhönite.

Similar to metasomatic mantle amphibole, the compositions of Changle rhönites cover the I-Amph (Iamphibole) and S-Amph (S-amphibole) fields, indicating that they may have formed due to an intraplate metasomatic event, overprinting an older metasomatic subduction episode.
\end{abstract}




\section{Introduction}

High-Ti minerals discovered in the Cenozoic alkali basalts of the Changle area (Shandong Province, China) were shown to be rhönite by Johnston and Stout (1985). Regrettably, the mineral name is spelled in different ways, such as rhoenite (Johnston and Stout, 1985; Grützner et al., 2013), rhonite (Anan'ev and Selyangin, 2011) or rhönite (Kunzmann, 1989, 1999; Grapes et al., 2003; Treiman, 2008; Grapes and Keller, 2010; Sharygin et al., 2011). The official name according to the Commission on New Minerals, Nomenclature and Classification (CNMNC) of the International Mineralogical Association (IMA) is rhönite and refers to the Rhön, a low mountain range in Germany found along the border region between Bavaria, Hesse and Thuringia.

Rhönite containing about $25 \mathrm{wt} \%-32 \mathrm{wt} \% \mathrm{SiO}_{2}$ had already been described by Vogelsang (1890) as a "dark hornblende". Brögger (1890) suggested that aenigmatite (later shown to be isostructural with rhönite) could be a triclinic member of the amphibole group; however, a crystallographic study later indicated that this was not the case (Palache, 1933). White (1966) and Johnston and Stout (1984) characterized rhönite as an "amphibole-like mineral". Later studies showed that rhönite is an aluminosilicate that is isostructural with aenigmatite (Bonaccorsi et al., 1990; Nédli and Tóth, 2003; Grew et al., 2008; Anan'ev et al., 2011), although Grew et al. (2008) considered it to be a member of the sapphirine supergroup. Sharygin et al. (2011) showed that rhönite has a broad range in $X_{\mathrm{Mg}}\left(\mathrm{Mg} /\left(\mathrm{Mg}+\mathrm{Fe}^{2+}\right)\right)$.

Besides being a primary magmatic mineral, for instance in pockets of basanitic rock, tephrite-phonolite, limburgite, teschenite or alkali basalt (Kunzmann, 1999; Grapes et al., 2003; Grapes and Keller, 2010; Kogarko et al., 2005; Sharygin et al., 2011; Grützner et al., 2013), rhönite is also known as a secondary mineral produced by alteration of kaersutite (Wilshire et al., 1971; Johnston and Stout, 1985) or Ti-bearing amphibole (Huckenholz et al., 1988; Kunzmann, 1999; Nédli and Tóth, 2003; Grapes et al., 2003). It was even described from Luna 24 basalt (Treiman, 2008). In alkali basalt, rhönite very rarely occurs as a phenocryst but is more common as a constituent of the fine-grained groundmass (Kogarko et al., 2005) and can also form an interstitial phase in basalt of Klyuchevskaya Sopka, Kamchatka (Anan'ev and Selyangin, 2011). Furthermore, rhönite compositional series can develop in paralava from the combustion of metamorphic rocks (Peretyazhko et al., 2017). Khesinite, a new member of the rhönite group, was recently discovered in thin veins of paralava within gehlenite-rich rocks in hornfels from the Hatrurim Complex in the Negev, Israel (Galuskina et al., 2017). Rhönite is also observed in metamorphosed calcic xenoliths from the Bellerberg paleovolcano of the Eifel area in Germany (Shchipalkina et al., 2019). Minerals associated with rhönite are typically titanaugite, kaersutite, diopside, forsterite, spinel, perovskite, magnesioferrite and titanomagnetite (Anan'ev and Selyangin, 2011).
A growing number of discoveries of rhönite in alkaline effusives during the last decades show that this mineral plays an important role in the geochemical evolution of crystallizing magma or lava (Kunzmann, 1989, 1999; Grapes et al., 2003; Treiman, 2008; Grapes and Keller, 2010; Sharygin et al., 2011; Grützner et al., 2013). Rhönite-bearing assemblages can be used for a rough estimate of temperature, pressure and oxygen fugacity during the crystallization of alkali basalt (Sharygin et al., 2011) and can also serve as important general indicators for primary magma evolution (Anan'ev and Selyangin, 2011). However, information on the petrographic interrelationships with other minerals is very scarce (Sharygin et al., 2011). Thus the detailed petrological and geochemical study of rhönite presented in the current work can provide important information on its genesis and the evolution of the host rock in general. Regarding the Cenozoic alkali basalt from Changle, the present study provides new insights into processes of crystallization from siliceous melts and mechanisms of secondary metasomatic formation at high temperatures.

\section{Geological background}

The Changle study area is located in Shandong Province in the western-central part of the North China Craton (NCC) and is closely related to the Tancheng-Lujiang (Tan-Lu) fault (Fig. 1), which separates western Luxi from eastern Jiaodong. The NCC is one of the oldest cratons $(3.8 \mathrm{Ga})$ on earth (Liu et al., 1992). However, it experienced lithospheric rejuvenation in the late Mesozoic and Cenozoic in that the cold, thick $(>180 \mathrm{~km})$ and depleted lithospheric mantle of the eastern NCC was replaced by a hot, thin $(80-60 \mathrm{~km})$, younger and fertile lithospheric mantle (Fan et al., 2000; Xu et al., 2004; Zhang et al., 2009). Lithospheric thinning generated intense magmatic activity (e.g. Zheng et al., 1998; Xu et al., 2004; Chen et al., 2006; Dai et al., 2016), of which Cenozoic volcanic rocks are the most typical representatives (Zou et al., 2000; Xu et al., 2017). In addition, the Tan-Lu fault, which is an active strike-slip zone with an extension of more than $5000 \mathrm{~km}$ in northeastern Asia (Zheng et al., 1998), is considered to be a major channel for ascending asthenospheric melts (Zheng et al., 1998; Xu et al., 2004; Chen et al., 2006). The erupted melts, which today represent the rhönitebearing Cenozoic alkali-olivine basalts, are a result of the fault systems active in northern Asia.

Despite much work that has been done on Cenozoic alkali basalt in the eastern part of the NCC, the sources of the melts and their characteristics remain a matter of debate $(\mathrm{Xu}$ et al., 2012). The Cenozoic alkali basalts typically show an intracontinental background and were generated in an extensional setting (Zou et al., 2000; Xu et al., 2005; Tang et al., 2006; Liu et al., 2008a; Chen et al., 2009). They are interpreted to represent melts that are derived from the asthenosphere with "OIB-type" geochemical features, such as an en- 


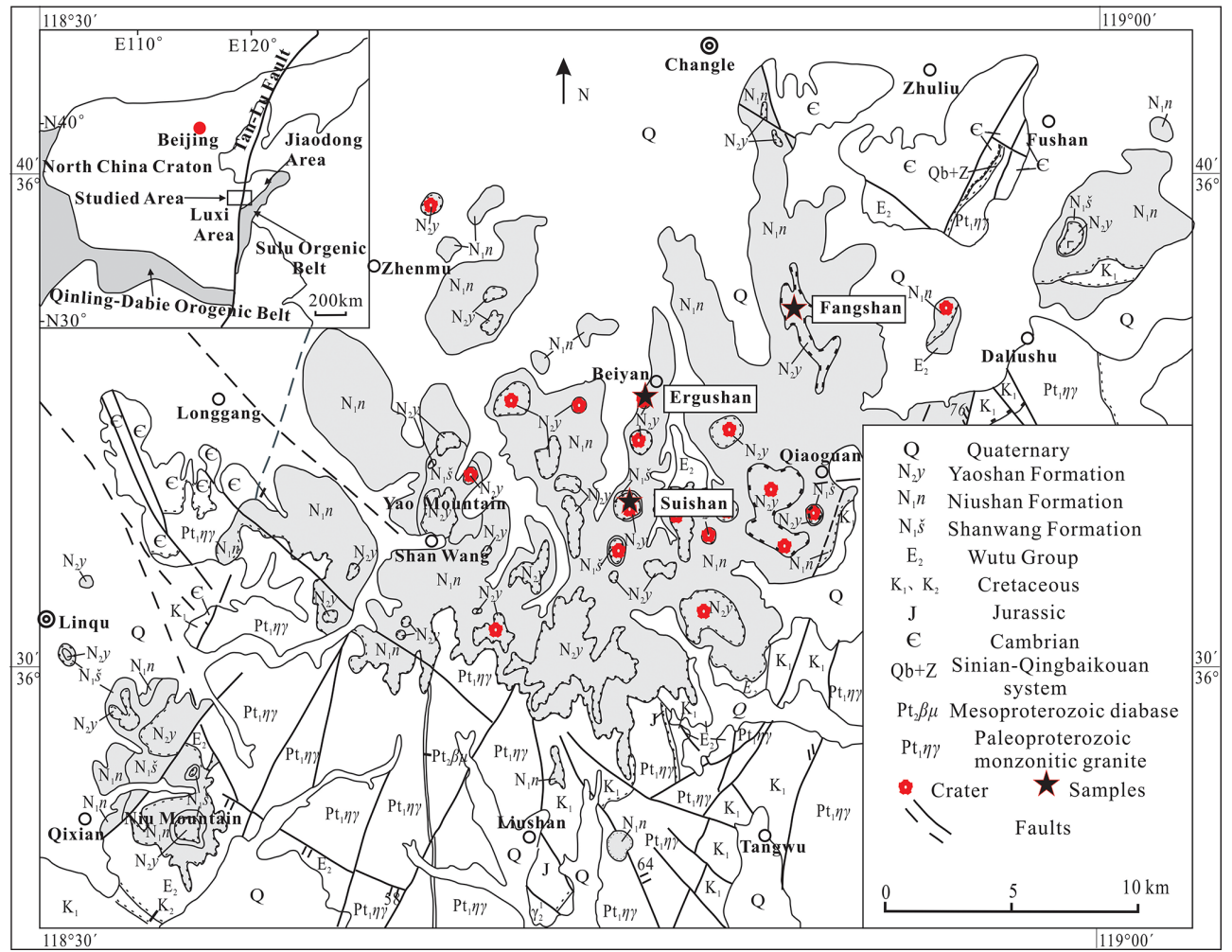

Figure 1. Geological sketch map of the study area (modified after Kong et al., 2017), indicating the sampling localities Fangshan, Ergushan and Suishan.

richment both of large-ion-lithophile (e.g. $\mathrm{Ba}, \mathrm{Rb}, \mathrm{Cs}, \mathrm{U}$ and $\mathrm{Sr}$ ) and high-field-strength elements (e.g. $\mathrm{Nb}$ and $\mathrm{Ta}$ ) and a depletion of K (Zeng et al., 2010). The basalts are also reported to have experienced crust-mantle interaction that is reported to have occurred in an old subduction channel (Dai et al., 2016; Li et al., 2017; Xu et al., 2017). The recycled components involved were derived mostly from the Pacific Plate and stored in the transition zone (Meng et al., 2018; Xu et al., 2018; Yu et al., 2018).

On the basis of $\mathrm{Sr}, \mathrm{Nd}, \mathrm{Pb}, \mathrm{Hf}$ and $\mathrm{Mg}$ isotope studies of Cenozoic basalts in eastern China, some authors have suggested that basalts with OIB-like trace-element patterns could be produced by metasomatism of large portions of the mantle wedge by interaction with partial melts derived from the Pacific slab (Li et al., 2017; Xu et al., 2017, 2018; $\mathrm{Li}$ and Wang, 2018). Three competing petrogenetic models are currently being discussed with regard to the evolution of OIB-like basalts. One model involves mantle metasomatism, where trace-element enrichment similar to OIB was produced by infiltration of small amounts of partial melts (Pilet et al., 2008; Xu et al., 2012). A second model favours a formation of the basalt due to recycling and assimilation of oceanic crustal melts (Hofmann and White, 1982; Dasgupta et al., 2010). Finally, Niu and O'Hara (2003) envisioned a model that considers subducted oceanic crust to become a source of OIBs after a recycling process.
Cenozoic volcanism in Shandong Province occurs in the Changle-Linqu, Yishui, Penglai, Qixia and Wudi areas (Zheng et al., 1998). The Changle-Linqu volcanics studied here occur within the Tan-Lu fault zone of the Luxi part (Xiao et al., 2010); more than 50 Cenozoic volcanoes are known (Fig. 1). The effusive rocks are predominantly represented by alkali-olivine basalt, olivine nephelinite and basanite (Zeng et al., 2010). Note that the Cenozoic magmatic events in Shandong took place during two periods: 24.010.3 Ma and 8.7-0.3 Ma (Luo et al., 2009; Zeng et al., 2010). The older of these two periods of magmatism is characterized by the formation of large volcanoes; the major rock type is an alkali-olivine basalt, called "weakly alkaline basalt" by Zeng et al. (2010). The younger period is characterized by the formation of small and isolated volcanoes and dominated by basanite and nephelinite ("strongly alkaline basalt" as defined by Zeng et al., 2010).

The earlier magmatic period of Cenozoic basalt formation is subdivided into two stages, called the Niushan and Yaoshan stages, which have been dated $\left({ }^{40} \mathrm{Ar} /{ }^{39} \mathrm{Ar}\right)$ at $21.0 \pm 2.5 \mathrm{Ma}$ and $17.3 \pm 1.5 \mathrm{Ma}$, respectively ( $\mathrm{He}$ et al., 2011a). The rock types include alkali basalt, olivine basalt and basanite. The samples of the present study belong to the Yaoshan event and originate from Fangshan, about $10 \mathrm{~km}$ south of Changle, Ergushan and Suishan (Fig. 1). The Ergushan and Suishan hills are close to each other and just 
south of the town of Beiyan (Fig. 1); these two localities are next to the Shanwang volcanic region near Linqu (Zheng et al., 1998).

As an interesting feature, megacrysts of corundum, spinel and olivine (Hu et al., 2007; He et al., 2011b; Zhao et al., 2015; Kong et al., 2017) and mantle xenoliths of low$\mathrm{Mg}^{\#}$ (the ratio of $\mathrm{Mg} /\left(\mathrm{Mg}+\mathrm{Fe}^{2+}\right)$ ) peridotite (Zheng et al., 1998; Xiao et al., 2010, 2013) are found in these basalts; detailed petrological and geochemical studies suggest that they represent fragments of newly accreted lithospheric mantle (Xiao et al., 2010; Su et al., 2014). Examples of both megacrysts and xenoliths are found in the present suite of studied samples.

\section{Analytical techniques}

Major and trace elements of rhönite were analysed using a JXA-8800R electron microprobe at the Key Laboratory of Orogenic Belts and Crustal Evolution, School of Earth and Space Sciences, Peking University, operating at an acceleration voltage of $15 \mathrm{kV}$ and a beam current of $20 \mathrm{nA}$. Natural and synthetic standards from the SPI company (Structure Probe, Inc.) of the United States used for calibration were jadeite $(\mathrm{Si})$, forsterite $(\mathrm{Mg})$, hematite $(\mathrm{Fe})$, albite $(\mathrm{Na}, \mathrm{Al})$, rutile $(\mathrm{Ti})$, rhodonite $(\mathrm{Mn})$, diopside $(\mathrm{Ca})$, sanidine $(\mathrm{K})$, nickel silicide $(\mathrm{Ni})$ and chromium oxide $(\mathrm{Cr})$. An approximate error for these analyses is $0.01 \mathrm{wt} \%$; representative microprobe analyses are listed in Tables 1 and 4.

Trace-element analyses were performed using an Agilent 7500ce inductively coupled plasma mass spectrometer (ICPMS), and laser ablation analyses were carried out using a pulsed $193 \mathrm{~nm}$ Ar excimer laser with $6 \mathrm{~J} \mathrm{~cm}^{-2}$ energy at a repetition rate of $5 \mathrm{~Hz}$ and with beam sizes between 32 and $60 \mu \mathrm{m}$, which were chosen according to the size of the measured mineral. The helium carrier gas flow velocity was $0.651 \mathrm{~min}$. Data reduction was performed using the GLITTER 4.4.2 software (Macquarie University). Calibration was performed using USGS reference glasses (Liu et al., 2008b, 2010). USGS reference material was analysed twice every five analyses. Detection limits were $0.02-0.05 \mathrm{ppm}$ for rareearth elements (REE). Representative ICP-MS analyses are listed in Table 2.

\section{Petrographical and mineralogical characteristics}

Mineral abbreviations in this paper are taken from Kretz (1983). Rhönite is abbreviated as Rhoe.

\subsection{Petrographical features of Changle rhönite}

All rhönite-bearing samples originate from alkali-olivine basalt that belongs to the Yaoshan stage. Samples CL01 and CL04 are from Fangshan; samples EGS03 and SS17 are from Ergushan and Suishan, respectively, south of the town of
Beiyan (Fig. 1). The modal amount of rhönite in each sample is about $1 \%$.

In the four studied rock samples, the respective type of rhönite occurrence is different (Figs. 2-3). (1) In sample CL01 rhönite forms anhedral granular grains which are part of a reaction rim around coarse-grained millimetrecentimetre-sized corundum crystals (Fig. 2a). A backscattered electron (BSE) image (Fig. 2b) shows that the reaction rim consists of different zones. Corundum is surrounded by a narrow inner reaction rim of spinel that itself is enveloped by a second rim consisting of fine-grained Tibearing magnetite (Ti-Mag in Figs. 2 and 3), which forms intergrowth textures with rhönite and alkali feldspar, locally also with clinopyroxene (Fig. 2b, c). Rhönite is very fine-grained, with individual crystals not exceeding $90 \mu \mathrm{m}$ in length. (2) In sample CL04, euhedral-anhedral grains of rhönite occur in embayments and outer parts of millimetrecentimetre-sized spinel crystals (Fig. 2d-f) and coexist with fine-grained phlogopite (Fig. 2e), Ti-bearing magnetite and alkali feldspar, locally also with fine-grained clinopyroxene (Fig. 2f). Fragments of mantle xenoliths associated with coarse-grained spinel do not contain rhönite, neither in the xenolith itself nor at its rim in contact with the basalt (Fig. 2d). (3) In sample EGS03, fine-grained acicular rhönite develops in a contact zone between early coarse-grained olivine and titaniferous phlogopite (Fig. 3a, b). Rhönite is also an important constituent of reaction's rim around phlogopite (Fig. 3a, b) and in addition develops along cleavage planes and cracks in phlogopite (Fig. 3c). Rhönite coexists with Ti-bearing magnetite (Fig. 3b) and alkali feldspar (Fig. 3c), locally also with late fine-grained olivine (Fig. 3c). (4) Sample SS17 represents a distinct occurrence of rhönite because here it forms euhedral grains in broken and locally metasomatically altered parts of mantle xenoliths in basalt (Fig. 3d). It is associated with grey spinel, clinopyroxene, late fine-grained olivine, alkali feldspar and former melt; some rhönite grains are agglomerated to form a synneusis texture (Fig. 3e, f). On the basis of the features described here, all types of rhönite studied are interpreted to represent the reaction product of melt with an early primary magmatic mineral.

\subsection{Structural formula and chemical composition of rhönite}

The structure of rhönite was described by Walenta (1969) and Deer et al. (1978) and discussed together with that of aenigmatite, which is isostructural. Rhönite is triclinic and has the general formula $X_{2} Y_{6} Z_{6} O_{20}$ (Deer et al., 1978; Johnston and Stout, 1985; Anan'ev and Selyangin, 2011), where the 8-fold coordinated $X$ site contains $\mathrm{Na}^{+}$and $\mathrm{Ca}^{2+}$ (plus additional $\mathrm{Fe}^{2+}$ if the sum of 2 atoms per formula unit - pfu - is not reached); 6-fold coordinated cations ( $Y$ site $)$ are $\mathrm{Ti}^{4+}, \mathrm{Mg}^{2+}$, $\mathrm{Fe}^{2+}, \mathrm{Fe}^{3+}, \mathrm{Al}^{3+}, \mathrm{Mn}^{2+}, \mathrm{Cr}^{3+}, \mathrm{Ti}^{3+}, \mathrm{Ca}^{2+}, \mathrm{Sb}^{5+}, \mathrm{Nb}^{5+}$ and $\mathrm{As}^{5+}$; and 4-fold coordinated cations in the $Z$ site are $\mathrm{Si}^{4+}$, $\mathrm{Be}^{2+}, \mathrm{B}^{3+}, \mathrm{Al}^{3+}$ and $\mathrm{Fe}^{3+}$ (Kunzmann, 1999). The classifi- 


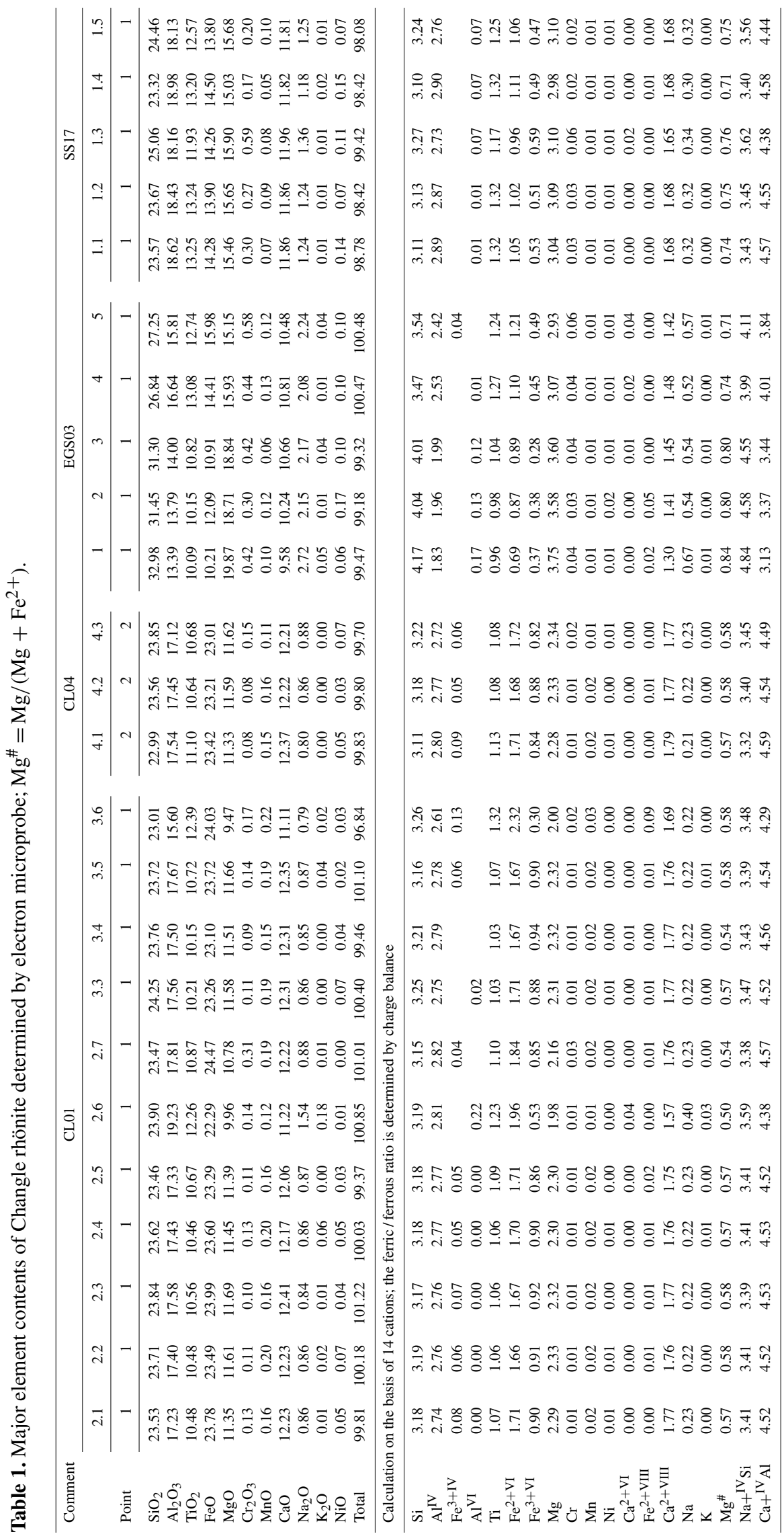




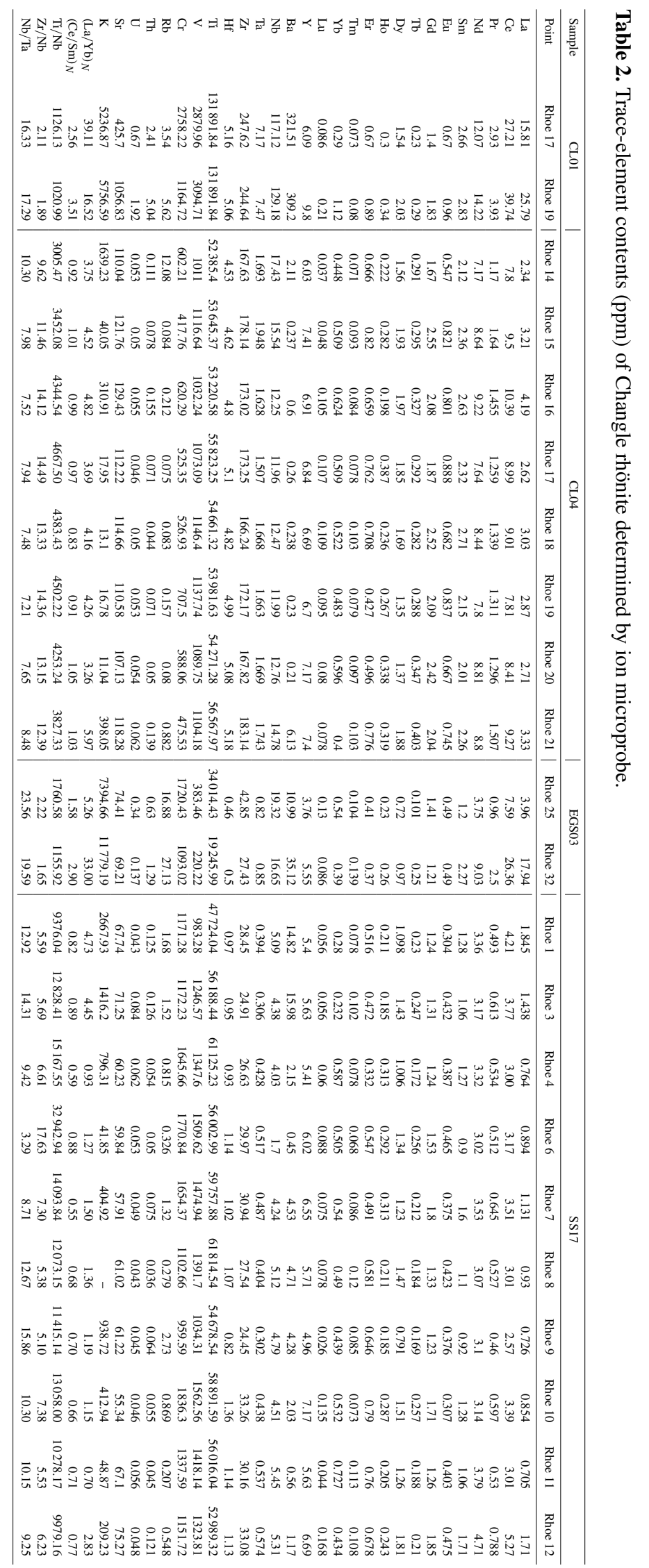




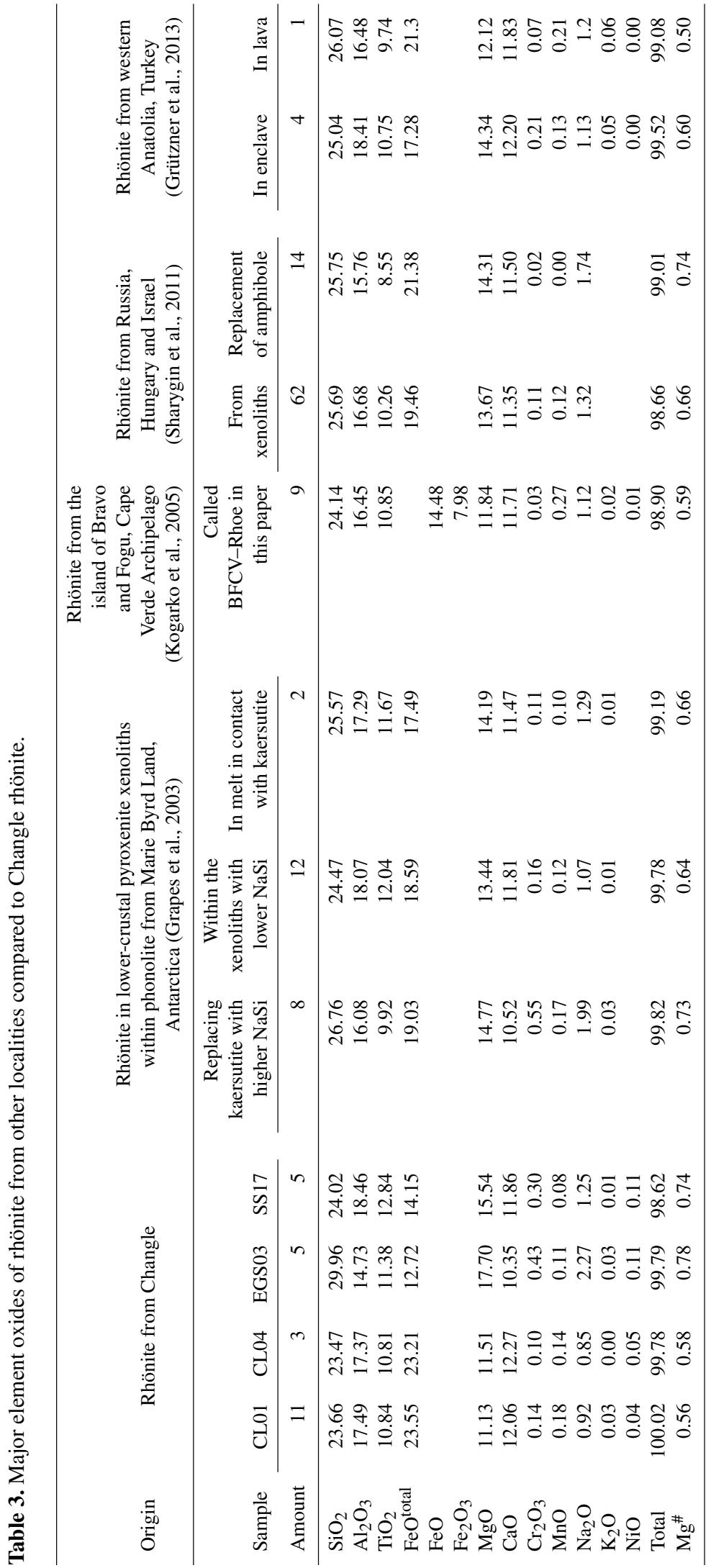




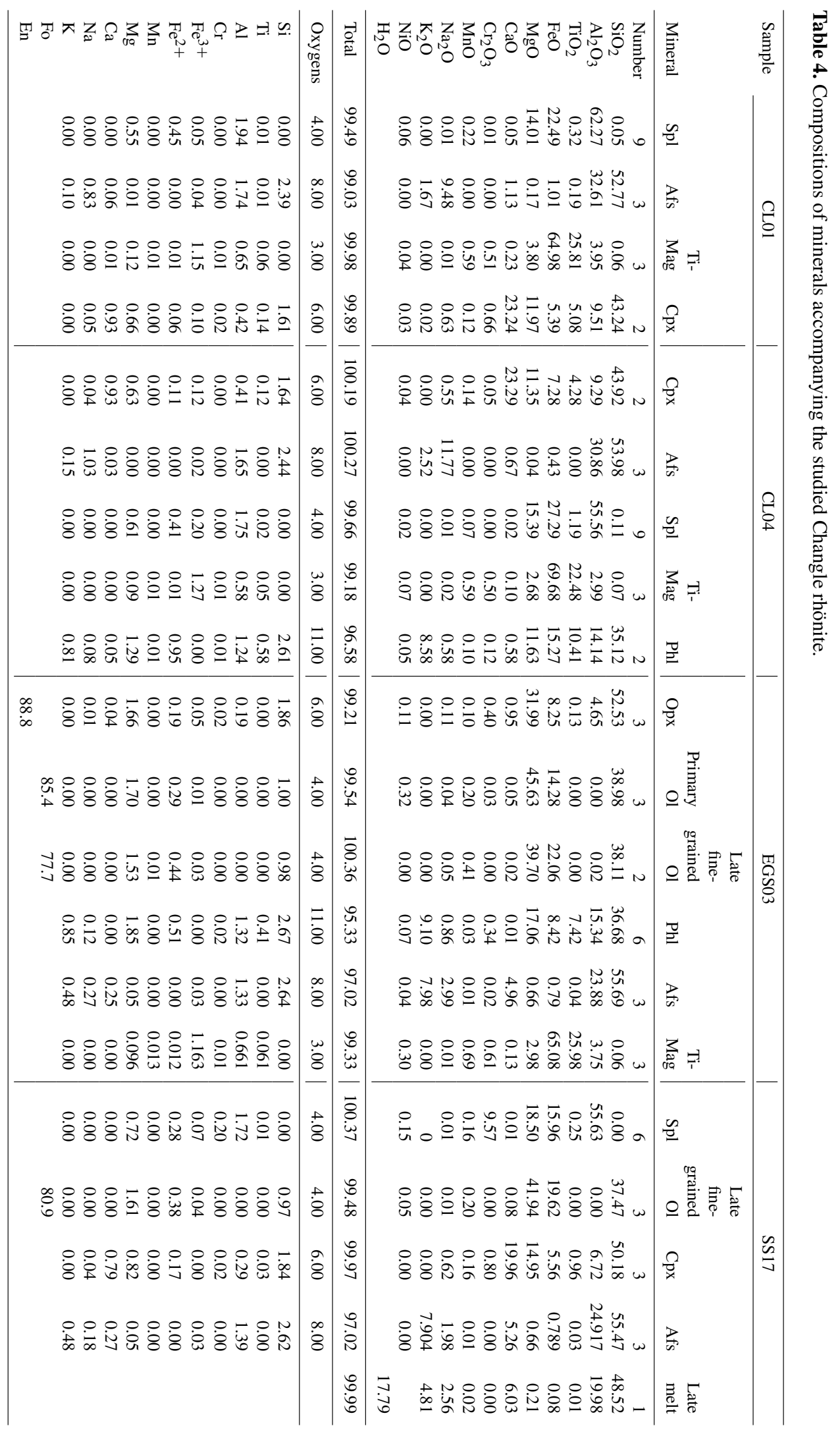




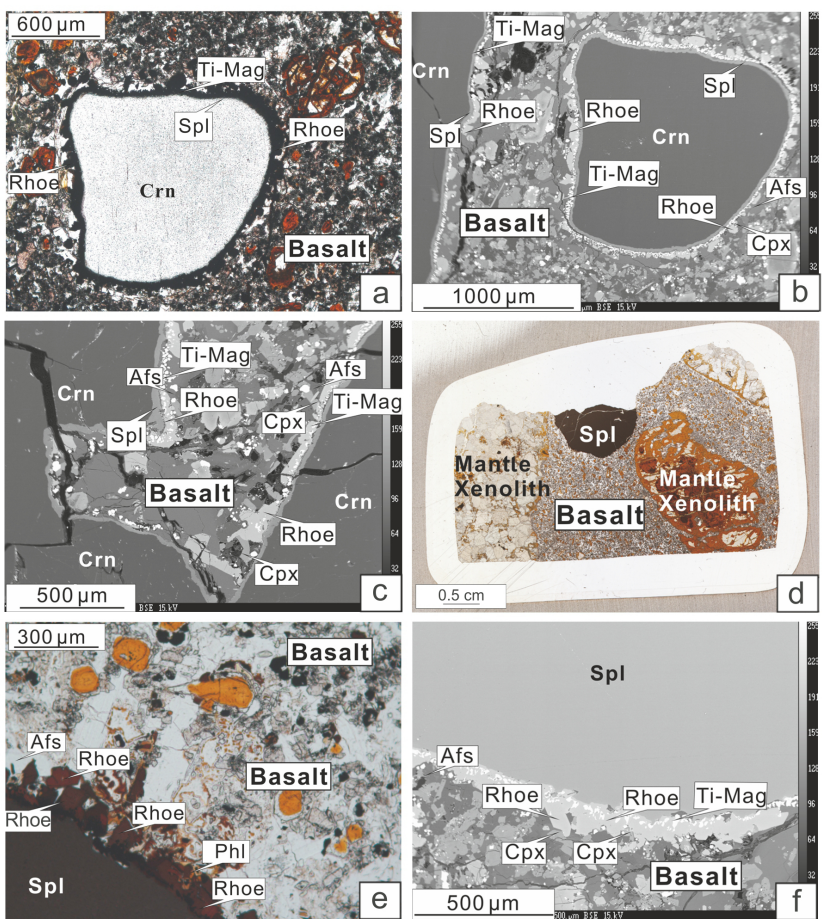

Figure 2. Microphotographs of rhönite-bearing samples CL01 (ac) and CL04 (d-f) from Fangshan. (a) Corundum megacryst in basalt with fine-grained reaction rim. (b) Same as (a) but in backscattered electron (BSE) mode. Note that an inner rim of spinel is located around corundum, surrounded by a rim of Ti-bearing magnetite (white) and a coarse-grained outermost rim of rhönite + alkali feldspar + clinopyroxene. (c) Pocket of basalt between corundum megacrysts with reaction rim as in (b). (d) Thin-section image of a spinel megacryst and mantle xenoliths in basalt. (e) Spinel megacryst with rhönite-bearing reaction rim. (f) Spinel with reaction rim of rhönite + Ti-bearing magnetite. $(\mathbf{a}, \mathbf{d}, \mathbf{e})$ Plane-polarized light (PPL); (b, c, f) BSE.

cation analysis of Kunzmann (1999) shows that the following three substitutions can be used to describe compositional variability for rhönite if rare substitutions involving $\mathrm{B}, \mathrm{Be}$ and $\mathrm{Sb}$ are neglected (see also discussion in Johnston and Stout, 1985):

(I) $\mathrm{Si}^{\mathrm{IV}}+\mathrm{Na}^{\mathrm{VIII}} \leftrightarrow\left(\mathrm{M}^{3+}\right)^{\mathrm{IV}}+\mathrm{Ca}^{\mathrm{VIII}}$,

(II) $\mathrm{Si}^{\mathrm{IV}}+\left(\mathrm{M}^{2+}\right)^{\mathrm{VI}} \leftrightarrow \mathrm{Al}^{\mathrm{IV}}+\left(\mathrm{M}^{3+}\right)^{\mathrm{VI}}$,

(III) $\mathrm{Ti}^{4+\mathrm{VI}}+\left(\mathrm{M}^{2+}\right)^{\mathrm{VI}} \leftrightarrow 2\left(\mathrm{M}^{3+}\right)^{\mathrm{VI}}$,

where the main homovalent substituents are $\mathrm{Mg}, \mathrm{Fe}^{2+}$ and $\mathrm{Mn}^{2+}$ for $\mathrm{M}^{2+}$ and $\mathrm{Al}, \mathrm{Fe}^{3+}$ and $\mathrm{Cr}^{3+}$ for $\mathrm{M}^{3+}$.

The formulae for rhönite from Changle (Table 1) were calculated on the basis of 14 cations and 20 oxygens per formula unit (Kunzmann, 1999). The ferric/ferrous ratio was determined by charge balance.

With respect to the major elements, rhönite compositions vary widely (Table 1; Figs. 4-6). Rhönite in sam-
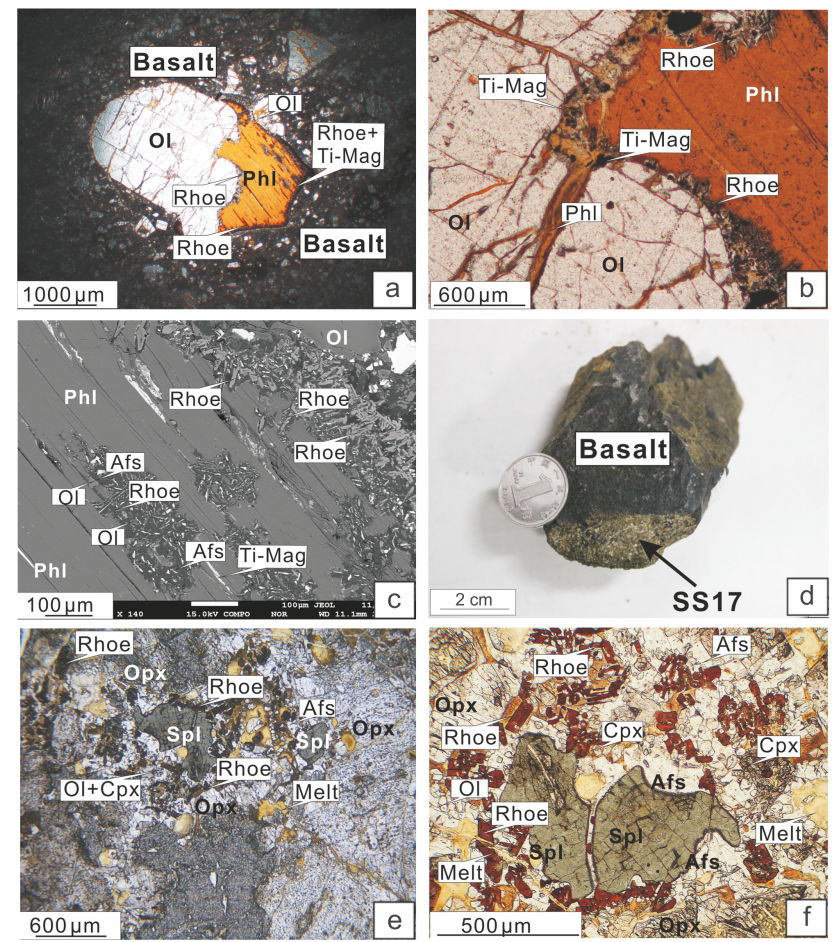

Figure 3. Microphotographs and hand-specimen photo of rhönitebearing samples EGS03 (a-c) from Ergushan and SS17 (d-f) from Suishan. (a, b) Intergrowth texture of rhönite with olivine and phlogopite. (c) Fine-grained rhönite coexisting with Ti-bearing magnetite, olivine and alkali feldspar, both along phlogopite cleavage planes or as rims around phlogopite. (d) Xenolith in basalt. (e, f) Locally altered xenolith with rhönite forming intergrowth textures with spinel, clinopyroxene, olivine, alkali feldspar and former basaltic melt. (a, b, e, f) PPL. (c) BSE. (d) Macrophotograph.

ple CL01 from Fangshan hill contains $9.47 \mathrm{wt} \%-11.69 \mathrm{wt} \%$ $\mathrm{MgO}$ and $22.29 \mathrm{wt} \%-24.47 \mathrm{wt} \% \mathrm{FeO}$, and in sample CL04 it contains $11.33 \mathrm{wt} \%-11.62 \mathrm{wt} \% \mathrm{MgO}$ and $23.01 \mathrm{wt} \%-$ $23.42 \mathrm{wt} \% \mathrm{FeO}$. Rhönite from the Ergushan and $\mathrm{Su}-$ ishan hills is considerably higher in $\mathrm{MgO}$ and lower in $\mathrm{FeO}$ and also much more variable (sample EGS03: $15.15 \mathrm{wt} \%-19.87 \mathrm{wt} \% \mathrm{MgO}, 10.21 \mathrm{wt} \%-15.98 \mathrm{wt} \% \mathrm{FeO}$; sample SS17: $15.03 \mathrm{wt} \%-15.68 \mathrm{wt} \% \mathrm{MgO}, 13.80 \mathrm{wt} \%$ $14.50 \mathrm{wt} \% \mathrm{FeO})$. Clearly, rhönite in the xenolith in sample SS17 and associated with phlogopite in sample EGS03 has more $\mathrm{MgO}$ and is lower in $\mathrm{FeO}$ than rhönite enclosing the spinel megacryst in sample CL04 or rhönite in reaction rims around corundum in sample CL01 (Table 1; Fig. 4). The compositional range of rhönite with respect to $\mathrm{MgO}, \mathrm{FeO}$, $\mathrm{Cr}_{2} \mathrm{O}_{3}$ and $\mathrm{MnO}$ is also much narrower in samples CLO1 and CL04 than in SS17 or EGS03 (Table 1; Fig. 4). In addition, note that although the contents of $\mathrm{Al}_{2} \mathrm{O}_{3}, \mathrm{SiO}_{2}$ and $\mathrm{Na}_{2} \mathrm{O}$, and $\mathrm{CaO}$ in samples EGSO3 and SS17 vary much more than in CL01 and CL04, the chemical substitutional trends in the Ergushan and Suishan samples are quite similar (Fig. 5). 

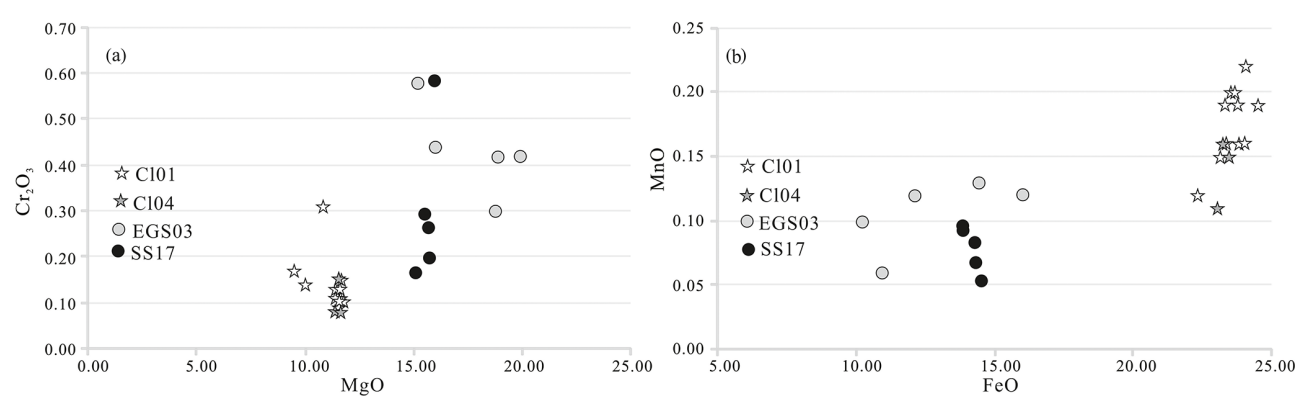

Figure 4. Diagrams of $\mathrm{Cr}_{2} \mathrm{O}_{3}$ versus $\mathrm{MgO}$ and $\mathrm{MnO}$ versus $\mathrm{FeO}$ showing systematic compositional variations in the Changle rhönites.
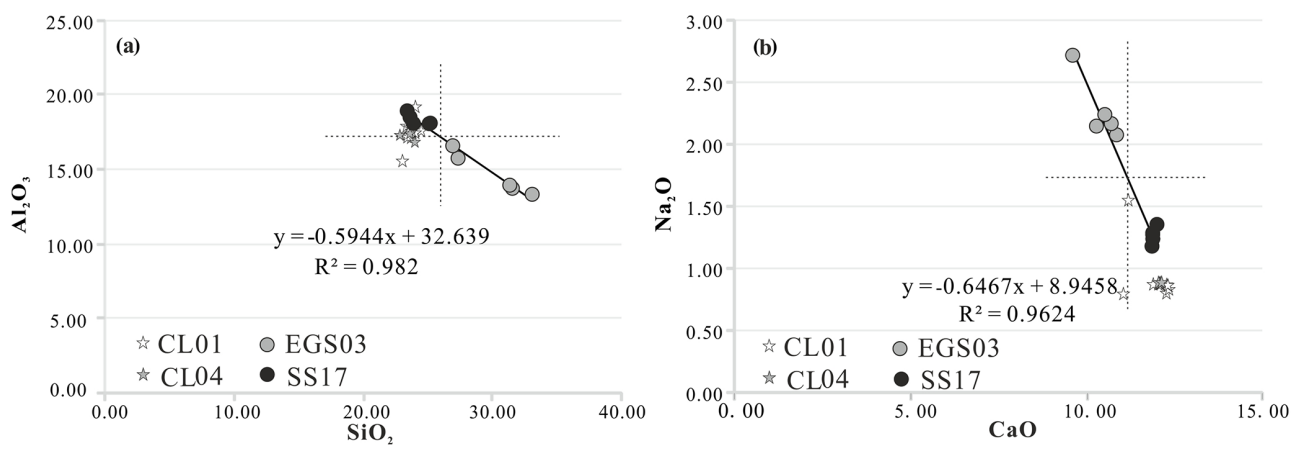

Figure 5. Correlation diagrams of $\mathrm{Al}_{2} \mathrm{O}_{3}$ versus $\mathrm{SiO}_{2}$ and $\mathrm{Na}_{2} \mathrm{O}$ versus $\mathrm{CaO}$ of Changle rhönite from samples $\mathrm{SS} 17$ and EGS03 (stars indicate rhönite from samples CL01 and CL04 for comparison). Dashed lines emphasize that the different sample populations can be distinguished on the basis of the contents of $\mathrm{Al}_{2} \mathrm{O}_{3}, \mathrm{SiO}_{2}, \mathrm{Na}_{2} \mathrm{O}$ and $\mathrm{CaO}$.

A wide range in compositions (Table 1) is also seen in $\mathrm{SiO}_{2} \quad(22.99 \mathrm{wt} \%-32.98 \mathrm{wt} \%), \mathrm{Al}_{2} \mathrm{O}_{3} \quad(13.39 \mathrm{wt} \%-$ $19.23 \mathrm{wt} \%), \quad \mathrm{MgO} \quad(9.47 \mathrm{wt} \%-19.87 \mathrm{wt} \%), \quad \mathrm{TiO}_{2}$ (10.09 wt \%-13.25 wt \%), $\mathrm{FeO} \quad(10.21 \mathrm{wt} \%-24.47 \mathrm{wt} \%)$, $\mathrm{CaO}$ (9.58 wt \%-12.41 wt \%) and $\mathrm{Na}_{2} \mathrm{O} \quad(0.79 \mathrm{wt} \%-$ $2.72 \mathrm{wt} \%$ ). Cation correlation (Fig. 6) shows that both $\mathrm{Al}$ and $\mathrm{Ca}$ are negatively correlated with $\mathrm{Si}$ (Fig. 6a, b), whereas $\mathrm{Si}$ is positively correlated with $\mathrm{Na}$ (Fig. 6c) and $\mathrm{Ca}$ is positively correlated with $\mathrm{Al}$ (Fig. 6d). In addition, $\mathrm{Fe}^{2+}$ is negatively correlated with $\mathrm{Mg}$ (Fig. 6e), and $\mathrm{Fe}^{3+\mathrm{VI}}$ is negatively correlated with $\mathrm{Ti}^{\mathrm{VI}}+\mathrm{Mg}^{\mathrm{VI}}+\mathrm{Fe}^{2+\mathrm{VI}}+\mathrm{Mn}^{\mathrm{VI}}$ (Fig. 6f). Thus, the following substitutions describe compositional variations in Changle rhönite:

1. $\mathrm{Si}^{\mathrm{IV}}+\mathrm{Na}^{\mathrm{VIII}} \leftrightarrow\left(\mathrm{Al}, \mathrm{Fe}^{3+}\right)^{\mathrm{IV}}+\mathrm{Ca}^{\mathrm{VIII}}$,

2. $\mathrm{Mg}^{\mathrm{VI}} \leftrightarrow\left(\mathrm{Fe}^{2+}, \pm \mathrm{Mn}^{2+}\right)^{\mathrm{VI}}$,

3. $\mathrm{Ti}^{\mathrm{VI}}+\left(\mathrm{Mg}+\mathrm{Fe}^{2+}+\mathrm{Mn}^{2+}\right)^{\mathrm{VI}} \leftrightarrow 2 \mathrm{Fe}^{3+\mathrm{VI}}$.

Note that substitutions (1) and (3) correspond to substitutions (I) and (III) of Kunzmann (1999). Substitution (2) describes a straightforward homovalent exchange.

The analyses obtained in this study (Table 1) agree with the general compositional definition of Grew et al. (2008) for rhönite within the sapphirine supergroup, and thus this name is used here. Kunzmann (1999) suggested a more detailed classification scheme for the "aenigmatite-rhönite mineral group". In terms of the Kunzmann scheme, rhönite from Changle shows $\mathrm{Na}<1$ at the $X$ site and $0.5<\mathrm{Ti}<1.5$ at the $Y$ site, conforming to his "rhönite subgroup". However, Kunzmann (1999) restricts rhönite s.s. (sensu stricto) to analyses conforming to $3<(\mathrm{Si}-\mathrm{Na})<4$, whereas the majority of Changle rhönite analyses show $2<(\mathrm{Si}-\mathrm{Na})<3$. Kunzmann (1999) notes that many "rhönite" analyses in the literature are similar and suggests that a new name should be found for such compositions in the future. Generally, the $\mathrm{Mg}^{\#}$ $\left[\mathrm{Mg} /\left(\mathrm{Mg}+\mathrm{Fe}^{2+}\right)\right]$ of Changle rhönite is in the range of $0.5-$ 0.84 (average of 0.65 ; Table 1); these values are similar to rhönite reported from enclaves in basanitic volcanics from western Anatolia in Turkey (Grützner et al., 2013), which all belong to the Mg-rich species (Sharygin et al., 2011) (Table 3). In general, rhönites with higher $\mathrm{Mg}^{\#}(0.71-0.84)$, as in samples SS17 and EGS03, also contain higher amounts of $\mathrm{Na}$ and Si than those with lower $\mathrm{Mg}^{\#}(0.5-0.58)$, as in samples CL01 and CL04 (Table 1; Fig. 5).

\section{Trace-element characteristics}

Rhönite typically forms a series of solid solutions (Shchipalkina et al., 2019), and Changle rhönite composition also varies (see Sect. 4) depending on the locality and the petrographical setting in thin section. Thus, apart from its variations in major-element composition, rhönite can also 

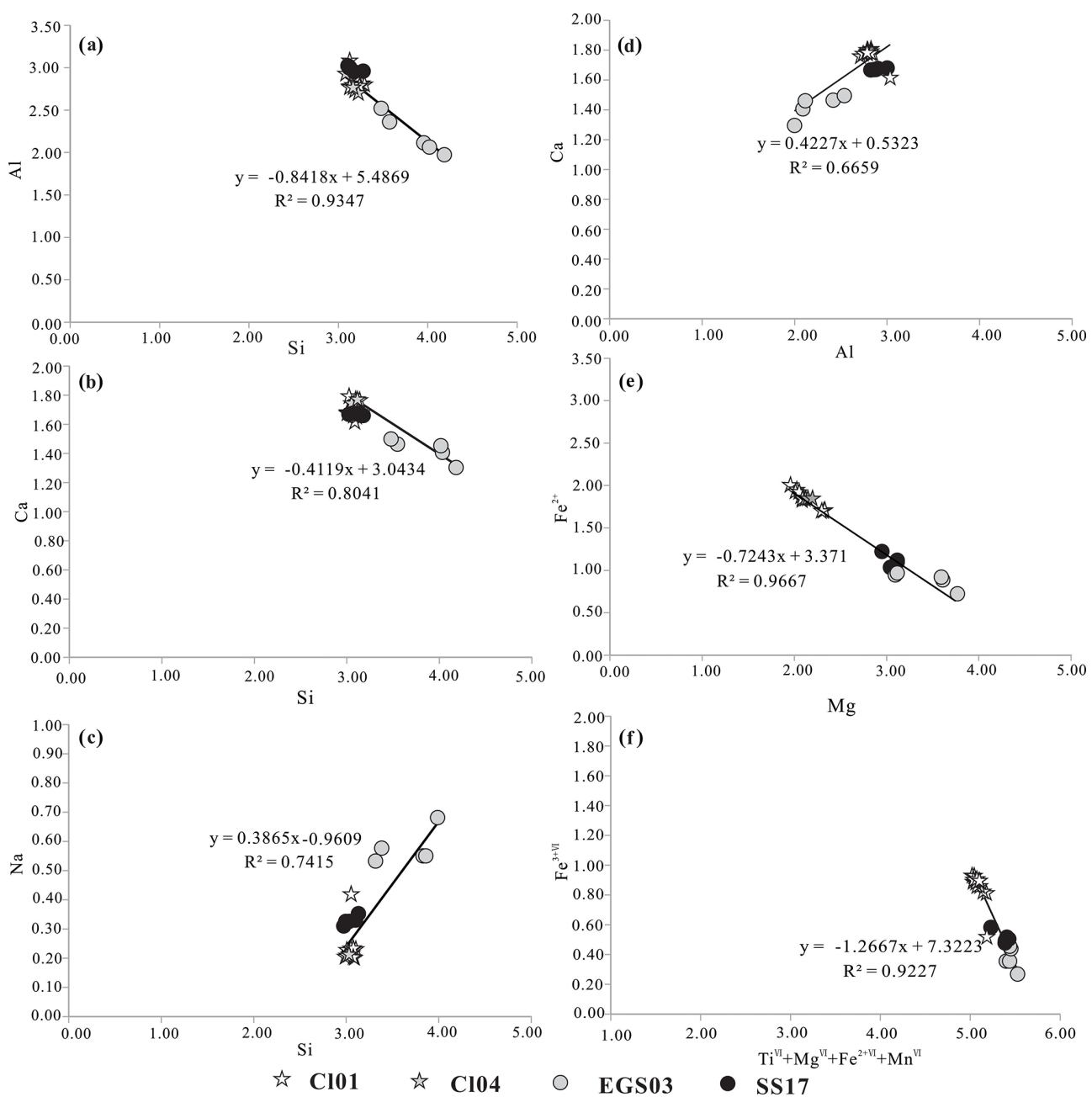

Figure 6. Correlation diagrams of selected major elements in Changle rhönite. Values along axes are given in atoms per formula unit.

be expected to exhibit distinctive features related to traceelement geochemistry. In order to document these characteristics, they are displayed in chondrite-normalized REE diagrams (Figs. 7, 8) and primitive-mantle normalized diagrams for incompatible elements (Fig. 9). Not much information is available from the literature, but Kogarko et al. (2005) presented trace-element data for rhönite from tephrite-phonolite on the islands of Bravo and Fogu, Cabo Verde archipelago (referred to as BFCV-Rhoes in this paper), which are given for comparison in Figs. 7 and 8. These islands are of volcanic origin and located along the African margin of the central Atlantic Ocean. They are interpreted as resulting from hotspot volcanism (Ramalho et al., 2010). Coltorti et al. (2010) suggested that the lavas are contaminated by old fragments of sub-continental lithospheric mantle. In Fig. 7 the REE patterns of OIBs (Sun and McDonough, 1989) are given for comparison as well.

\subsection{REE characteristics}

The REE patterns of rhönite from the three different localities of the Changle area are presented in Fig. 7. The REE patterns of rhönite from samples CL01 and EGS03 are distinctly different from those of samples CL04 and SS17 in that they are relatively steep (with $(\mathrm{La} / \mathrm{Yb})_{N}=5.26-39.11$; Table 2; Fig. 7). It is obvious that two of the Fangshan rhönite patterns (CL01-Rhoe 17 and CL01-Rhoe 19), show a pronounced increase towards the light rare-earth elements (LREEs) (Fig. 7a). Towards the heavy rare-earth elements (HREEs) a general decrease from Dy to Tm is observed, followed again by an increase towards Lu (CL01-Rhoe 17) (Fig. 7a). In general, the LREE content in rhönite from sample CL01 (Fig. 7a) is significantly higher than that from sample CL04 (Fig. 7b) from the same locality. The patterns of the two Ergushan rhönites (EGS03; Fig. 7c) show a pronounced enrichment in LREEs and a decrease towards HREEs. Regarding the LREEs, the amounts of $\mathrm{La}, \mathrm{Ce}, \mathrm{Pr}, \mathrm{Nd}, \mathrm{Sm}$ and $\mathrm{Tb}$ in rhönite of sample EGS03-Rhoe 32 are significantly 


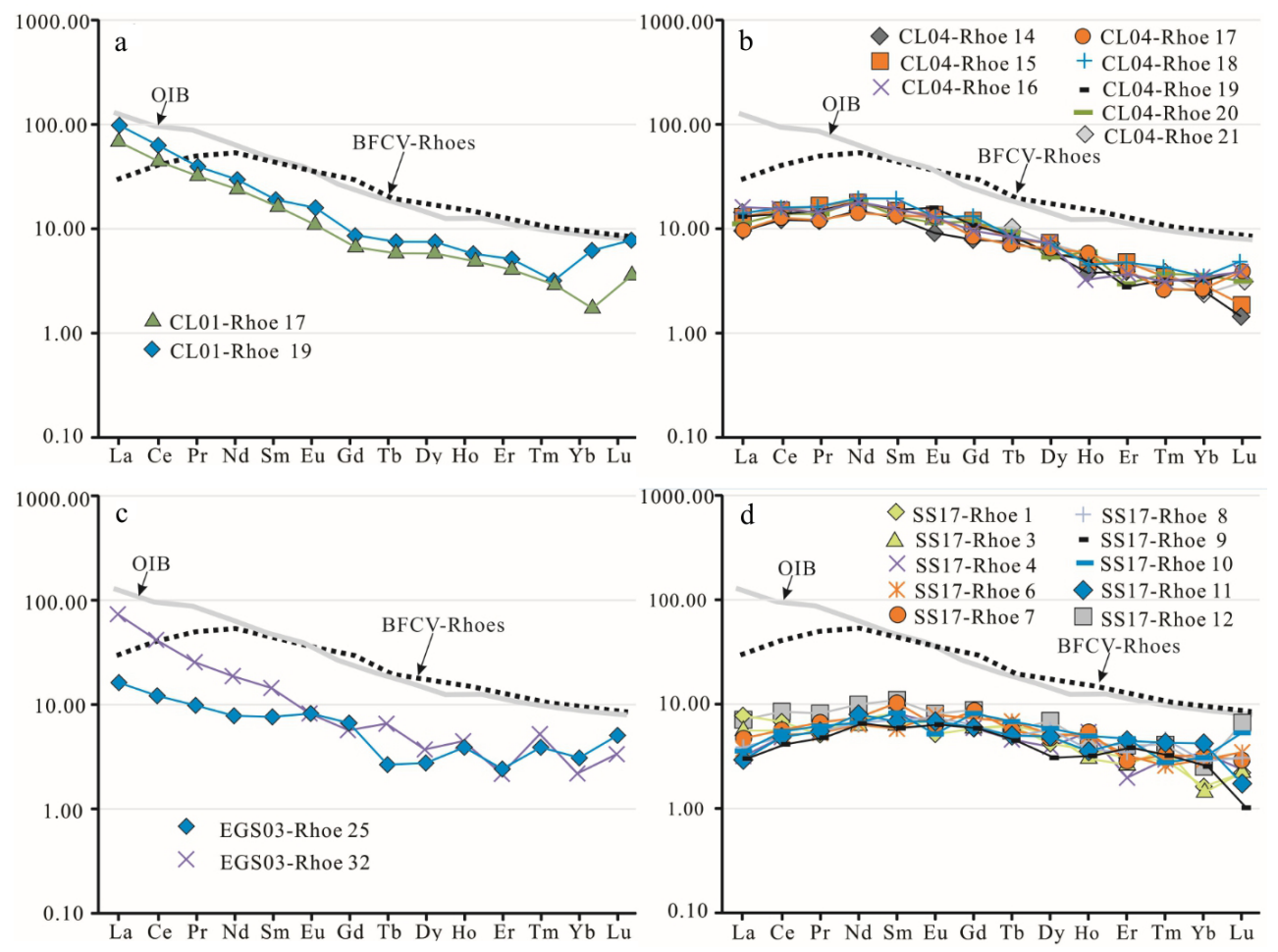

Figure 7. REE contents of Changle rhönite normalized to chondrite (Sun and McDonough, 1989) and compared to literature data. BFCVRhoes is rhönite from the islands of Bravo and Fogu, Capo Verde archipelago, from Kogarko et al. (2005); OIB is ocean island basalt from Sun and McDonough (1989).

higher than those in EGS03-Rhoe 25 (Fig. 7c). On the HREE side, the patterns are similar and marked by a zigzag pattern.

There is essentially no difference in REE chemistry between rhönite within the xenolith of sample SS17 and euhedral rhönite closely associated with spinel megacrysts of sample CL04. The respective REE patterns are slightly enriched in LREEs and show a decrease toward the HREEs, with $(\mathrm{Ce} / \mathrm{Sm})_{N}=0.55-1.05$ (Fig. 7b, d; Table 2). The rhönite patterns do not show any significant anomalies. Most of the rhönites from Fangshan (CL04) show a convex-upward shape, and, compared to rhönite from Suishan (SS17), the amount of LREEs is somewhat higher (Fig. 7b, d). Furthermore, the patterns of rhönite from Suishan (SS17) are generally relatively flat, with a slight convex-upward shape with a maximum at Sm (Fig. 7d). All 10 measured rhönite patterns from Suishan are similar to each other; only the amount of $\mathrm{Lu}$ is distinctively higher in samples SS17-Rhoe 10 and SS17Rhoe 12 and lower in SS17-Rhoe 9 (Fig. 7d).

The spectrum of REE patterns of Changle rhönite from samples SS17 and CL04 is most similar to BFCV-Rhoes of Kogarko et al. (2005), which is phenocrysts in tephritephonolite (Fig. 7). In general, the REEs of the Changle rhönite are more depleted than those studied by Kogarko et al. (2005; see Fig. 7). On the other hand, rhönite in samples EGS03 and CL01 shows a spectrum of patterns which is similar to that of OIB (Sun and McDonough, 1989) (Fig. 7a, c); however, the EGS03 and CL01 patterns are depleted compared to OIB.

Figure 8 shows the distinguishing features of all rhönite REE patterns from this study. It is obvious that the rhönite patterns from samples CL04 and SS17 are quite similar, except for higher amounts of LREEs in CL04. Figure 8 also shows that the spectrum of rhönite REE patterns from samples CL04 and SS17 is similar to that of kaersutitic amphibole megacryst in various types of alkalic basalt such as basanite, olivine nephelinite, transitional alkali-olivine basalt and hawaiite (Irving and Frey, 1984), and kaersutite from Cenozoic alkali basalt from the South China Sea (Yan et al., 2015), which, however, are generally more enriched in REE. Rhönite patterns from samples CL01 and EGS03 are enriched in LREEs and generally follow the trend of wholerock REE patterns of Changle weakly alkali basalt (Zeng et al., 2010), which are old basalts 24.0-10.3 Ma in age (Yu et al., 2010) and represent an important period of volcanism on Shandong peninsula.

\subsection{Incompatible-element characteristics}

In general, the primitive-mantle normalized diagrams for incompatible-element contents of all Changle rhönite samples indicate very similar trends; $\mathrm{Nb}, \mathrm{Ti}$ and $\mathrm{V}$ typically show a pronounced positive anomaly. In addition, the pat- 


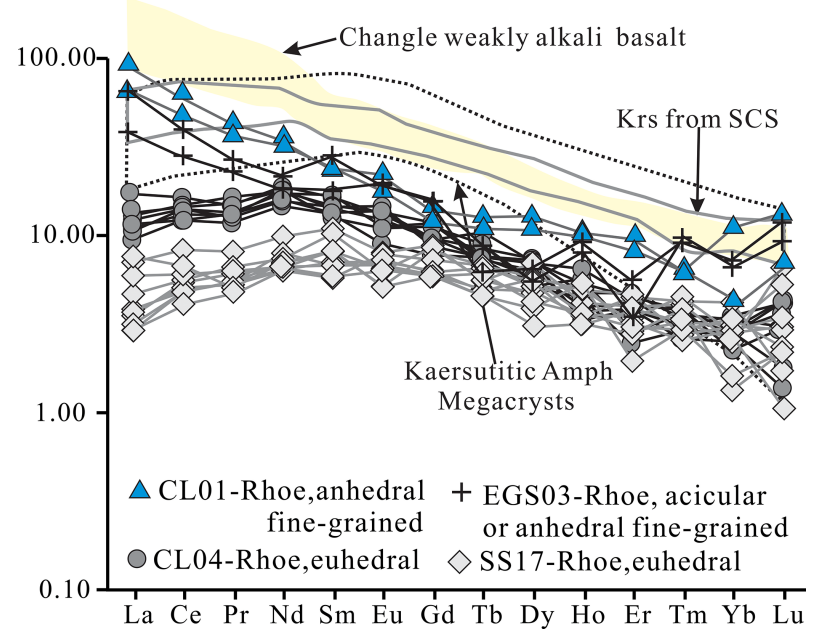

Figure 8. REE contents of Changle rhönite normalized to chondrite (Sun and McDonough, 1989) and compared to kaersutitic amphibole (Irving and Frey, 1984) and to weakly alkali basalt (Zeng et al., 2010). "Krs from SCS" is kaersutite from South China Sea, after Yan et al. (2015).

terns of samples CL01 (Fig. 9a) and CL04 (Fig. 9b) show a small positive $\mathrm{Zr}$ anomaly. A small positive $\mathrm{Sr}$ anomaly is observed only in rhönite from sample CL01 (Fig. 9a). As already observed in their REE patterns (Fig. 7c), the two samples from Ergushan differ significantly from each other, especially with respect to the LREEs, and similarly the incompatible elements (Fig. 9c) also demonstrate considerable differences. Figure 9c shows that sample EGS03-Rhoe 32 has substantially higher amounts of $\mathrm{Ba}, \mathrm{La}, \mathrm{Ce}$ and $\mathrm{Pr}$ compared to EGS03-Rhoe 25, in addition to $\mathrm{Nd}$ and $\mathrm{Sm}$ anomalies.

The spectrum of rhönite patterns from all three localities generally conforms to that of the rhönite sample from Kogarko et al. (2005), the host rock which is interpreted to have been derived from rocks of a hotspot-intraplate, oceanicisland environment. Although the patterns are similar and in part nearly identical, the Changle rhönites (with the exception of $\mathrm{Ba}, \mathrm{V}$ and $\mathrm{Cr}$ ) tend to be poorer in incompatible elements than those described by Kogarko et al. (2005) (Fig. 9ad). Note particularly that the rhönite patterns of sample CL04 (Fig. 9b) nearly mimic those from Kogarko et al. (2005), and even the positive $\mathrm{Zr}$ anomaly is present. The rhönite from sample CL01, in general agreement with sample EGS03, is somewhat enriched in highly incompatible elements. The rhönite pattern from sample SS17 is again quite similar to those described by Kogarko et al. (2005); nevertheless, the positive $\mathrm{Zr}$ anomaly is missing (Fig. 9d). Perhaps the rhönite from Kogarko et al. (2005) is more enriched in incompatible elements because the hosting rock is an alkali tephritephonolite dyke and not of basaltic composition, which then would result in differences in REE and trace elements in general.
In addition, it is noteworthy that in the spidergrams of Fig. 9 the incompatible elements of all studied rhönites demonstrate pronounced positive anomalies of $\mathrm{Ti}, \mathrm{Nb}$ and V (Fig. 9). Compared to associated minerals (such as spinel, clinopyroxene), rhönite has distinctly more $\mathrm{Ti}, \mathrm{V}$ and $\mathrm{Nb}$ except for the last-crystallized, fine-grained irregular ilmenite (data from unpublished author).

\section{Discussion}

\subsection{The formation of Changle rhönite in view of other occurrences}

The petrographical setting of rhönite, especially with respect to morphology and location in different parts of the magmatic fabric, gives important indications for the order of crystallization. Rhönite grains in samples SS17 and CL04 are euhedral and larger compared to rhönite from sample CL01 and the needle-like anhedral grains surrounding phlogopite or within the cleavage planes of phlogopite in EGS03. These petrographical features indicate that the larger, euhedral rhönite in SS17 and CL04 formed earlier than the smaller, anhedral or acicular grains in EGS03 and CL01. Despite having formed at different stages, all rhönite studied is interpreted to represent the product of a reaction of melt with early or primary minerals (Figs. 2, 3). Sample SS17 is a locally altered mantle xenolith, and rhönite possibly formed by reaction of a melt with coarse-grained orthopyroxene or spinel (Kong et al., 2013, 2015) (Fig. 3e-f).

The petrographical features and mineral relationships suggest that the following overall rhönite-forming reactions can be constructed. As further confirmation of these suggestions, the chemical analyses of the minerals reacting with rhönite are given in Table 4.

The reaction for the formation of anhedral rhönite as part of a narrow reaction zone surrounding spinel in sample CL01 (Fig. 2a-c) and of euhedral to anhedral rhönite in sample CL04 in embayments surrounding spinel (Fig. 2d-f) is

(1) spinel + melt $\rightarrow$ rhönite + Ti-bearing magnetite + alkali feldspar \pm clinopyroxene \pm phlogopite.

The reaction for the formation of fine-grained acicular rhönite in sample EGS03 that developed between an early olivine megacryst and phlogopite, or around the phlogopite or along cleavage planes and cracks in phlogopite (Fig. 3ac), is

(2) phlogopite/olivine megacryst + melt $\rightarrow$ rhönite + Tibearing magnetite \pm late fine-grained olivine + alkali feldspar.

The reaction for the formation of large euhedral rhönite in mantle xenolith (sample SS17; Fig. 3d-f) is

(3) orthopyroxene + early melt \pm primary spinel/olivine $\rightarrow$ rhönite + clinopyroxene + late olivine + late melt + 

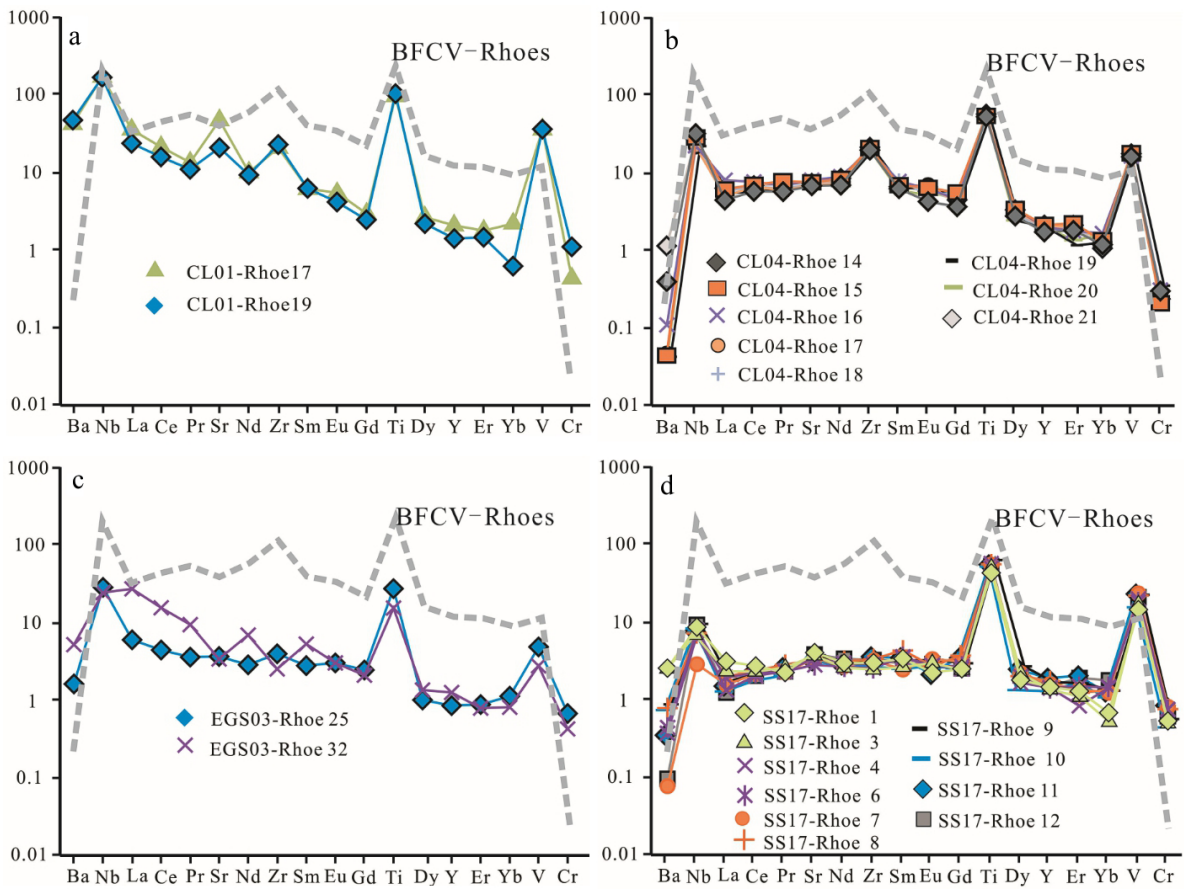

Figure 9. Spidergrams of rhönite normalized to primitive mantle (Sun and McDonough, 1989) and compared to rhönite from islands of Bravo and Fogu, Cabo Verde archipelago (BFCV-Rhoes), from Kogarko et al. (2005).

secondary spinel + alkali feldspar \pm Ti-bearing magnetite.

Although the Changle rhönites show considerable variations in major element compositions (Table 1; Figs. 4-6), some of them are similar to specific compositions of rhönite from other localities, for instance to those from tephritephonolite on the islands of Bravo and Fogu, Cabo Verde archipelago (BFCV-Rhoes; Kogarko et al., 2005); to rhönite in olivine phenocrysts from alkali-basaltic fields of Russia, Hungary and Israel (Sharygin et al., 2011); and to rhönite from basanitic volcanic rocks of the Quaternary Kula volcanic province in western Anatolia, Turkey (Grützner et al., 2013) (Table 3).

Note that rhönite from samples SS17 and EGS03 contains high amounts of $\mathrm{MgO}$ and $\mathrm{Cr}_{2} \mathrm{O}_{3}$ and low amounts of $\mathrm{FeO}$ and $\mathrm{MnO}$, whereas rhönite from samples CL04 and CL01 shows the opposite trend (Fig. 4). Correspondingly, Grützner et al. (2013) also observed different compositions of rhönite in the same rock. These authors showed that rhönite in enclaves from basanite in Turkey has higher $\mathrm{MgO}, \mathrm{Al}_{2} \mathrm{O}_{3}$ and $\mathrm{Cr}_{2} \mathrm{O}_{3}$ but lower $\mathrm{FeO}$ and $\mathrm{MnO}$ compared to the rhönite in the matrix of the basanite. Compared to the rhönite in the enclaves of Grützner et al. (2013), those in SS17 and EGS03 from Changle have higher $\mathrm{MgO}$ and $\mathrm{Cr}_{2} \mathrm{O}_{3}$ but lower $\mathrm{FeO}$ and $\mathrm{MnO}$, whereas the rhönite in CL01 and CL04 is similar to the matrix type of Grützner et al. (2013), which, however, is slightly higher in $\mathrm{FeO}, \mathrm{TiO}_{2}$ and $\mathrm{Cr}_{2} \mathrm{O}_{3}$ and lower in $\mathrm{SiO}_{2}$, $\mathrm{MgO}$ and $\mathrm{MnO}$. Thus, the chemical composition of Changle rhönite appears to depend to a large extent on the composition of the initial silicate melt.

Sharygin et al. (2011) confirmed that variations in rhönite composition can be correlated with the composition of the initial silicate melt and with the redox conditions during crystallization. Rhönite in EGS03 has a composition of higher $\mathrm{Na}$ and $\mathrm{Si}$ and lower $\mathrm{Ca}$ and $\mathrm{Al}$ and is similar to rhönite with $\mathrm{NaSi}$-rich and $\mathrm{CaAl}$-poor compositions in lower-crustal pyroxenite xenoliths within phonolite from the Mount Sidley composite volcano, Marie Byrd Land, Antarctica (Grapes et al., 2003). The latter are reported to indicate a formation at high oxidation conditions at a late growth stage (Grapes et al., 2003). Thus, the chemical composition of Changle rhönite also depends on the redox conditions during crystallization.

Rhönite is also reported to replace Ti-bearing amphibole or kaersutite (Wilshire et al., 1971; Johnston and Stout, 1985; Huckenholz et al., 1988; Kunzmann, 1999; Nédli and Tóth, 2003; Grapes et al., 2003). Note that high amounts of $\mathrm{Na}+\mathrm{Si}^{\mathrm{IV}}$ and low amounts of $\mathrm{Ca}+\mathrm{Al}^{\mathrm{IV}}$ are typical features of rhönite that is assumed to be a secondary phase produced by alteration of kaersutite, whereas primary rhönite is reported to contain low amounts of $\mathrm{Na}+\mathrm{Si}^{\mathrm{IV}}$ and high $\mathrm{Ca}+\mathrm{Al}^{\mathrm{IV}}$ (Nédli and Tóth, 2003; Grapes et al., 2003; Doroozi et al., 2016). In this respect, Changle rhönite from samples SS17, CL01 and CL04 conforms to the chemical characteristics of a primary phase and is low in $\mathrm{Na}+\mathrm{Si}^{\mathrm{IV}}$ and high in $\mathrm{Ca}+\mathrm{Al}^{\mathrm{IV}}\left(\mathrm{Na}+\mathrm{Si}^{\mathrm{IV}}: 3.38-3.62 ; \mathrm{Ca}+\mathrm{Al}^{\mathrm{IV}}: 4.29\right.$ 
4.59). From the perspective of petrographical observation, Changle rhönites are considered to be products of reactions of melt with spinel, phlogopite, olivine or orthopyroxene (Figs. 2 and 3). Only rhönite from the sample EGS03 shows chemical characteristics that are similar to those reported for secondary rhönite, replacing Ti-bearing amphibole or kaersutite (Fig. 3b, c; Table 1) (Nédli and Tóth, 2003; Grapes et al., 2003; Doroozi et al., 2016), although no Ti-bearing amphibole or kaersutite has been observed in this sample.

\subsection{The formation conditions of Changle rhönite}

Rhönite is often associated with titanian augite, kaersutite, diopside, clinopyroxene, forsterite, spinel, perovskite, magnesioferrite and titanomagnetite (Walenta, 1969; Kunzmann, 1989, 1999; Grapes et al., 2003; Treiman, 2008; Anan'ev and Selyangin, 2011; Grützner et al., 2013; Doroozi et al., 2016). Some of these minerals have also been documented in the Changle rocks as, for example, in the assemblage spinel + rhönite + alkali feldspar \pm clinopyroxene \pm phlogopite (Fig. 2e-f) and the assemblage spinel + rhönite + ternary feldspar + phlogopite (Fig. 3c). Although there are experimental data on rhönite stability relationships to constrain temperature, pressure and oxygen fugacity, there are, unfortunately, no experimental data on the dependence of rhönite chemistry on these parameters.

The most comprehensive experimental data on rhönite stability relationships have been provided by Kunzmann (1989; see also Kunzmann, 1999, for a summary). On its own composition, rhönite is stable at 1 bar from $850-1000^{\circ} \mathrm{C}$ to at least $5 \mathrm{kbar}$ at 900 to $1100^{\circ} \mathrm{C}$ (Kunzmann, 1989) at quite variable conditions of oxygen fugacity. For instance, Kunzmann $(1989,1999)$ reports experiments at 1 bar in which rhönite was synthesized under conditions of the $\mathrm{HM}$ (hematite-magnetite), NNO (Ni-NiO), QFM (quartzfayalite-magnetite) and IQF (iron-quartz-fayalite) oxygen buffers. However, for bulk compositions reflecting basaltic systems, the $P-T$ stability field of rhönite is much more restricted. Kunzmann (1989) documented the overlapping $P$ $T$ stability fields of Ti-rich calcium amphibole and rhönite for an alkali-basaltic system under NNO oxygen buffer conditions in the liquidus-solidus $P-T$ region (Fig. 10). Considering that Changle rhönite does not coexist with a Ti-rich amphibole and that Changle rhönite is part of an assemblage that includes Ti-bearing magnetite, feldspar, clinopyroxene and melt, a $P-T$ region of potential formation can be mapped out (Fig. 10). On the basis of Kunzmann's (1989) results, Changle rhönite could form in the temperature range from 950 to $1180^{\circ} \mathrm{C}$ at maximum pressures of $0.5 \mathrm{kbar}$, where the rhönite-out reaction curve is located (Fig. 10).

Boivin (1980) studied rhönite stability at 1 bar as a function of temperature and oxygen fugacity (IW is iron-wüstite; NNO) for bulk compositions equivalent to natural kaersutite, basanitoid (a rock intermediate between olivine basalt and basanite) and hawaiite. The results indicate that rhönite sta-

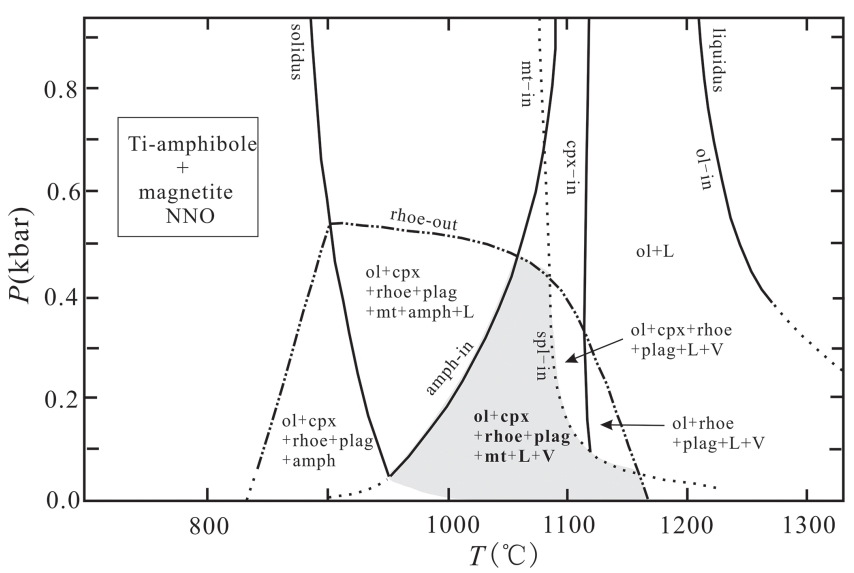

Figure 10. Liquidus-solidus relationships of Ti-rich calcium amphibole and rhönite in alkali basalt up to $1 \mathrm{kbar}$ at NNO oxygen buffer conditions after Kunzmann (1989); the stability field of Changle rhönite is shaded in light grey.

bility is not very sensitive to oxygen fugacity, as noted above, but depends strongly on bulk-rock composition. Going from the kaersutite to basanitoid and hawaiite bulk compositions, the contents of $\mathrm{TiO}_{2}$ and the modal foids nepheline and leucite decrease regularly (Boivin, 1980). At 1 bar, rhönite is stable up to ca. $1150^{\circ} \mathrm{C}$ (IW buffer) or $1170^{\circ} \mathrm{C}$ (NNO buffer) for kaersutite to ca. $1090^{\circ} \mathrm{C}$ (both buffers) for basanitoid composition. No rhönite was observed for the hawaiite composition. Thus undersaturated alkali-basaltic melts appear to be a prerequisite for rhönite crystallization, and higher $\mathrm{TiO}_{2}$ contents favour stability of rhönite to higher temperatures.

For a lack of suitable geobarometers, most studies involving rhönite have accepted the 500-600 bar upper pressure limit for rhönite experimentally derived by Kunzmann (1989). For the Cabo Verde rhönite occurrence, Kogarko et al. (2005) also used the experimental data of Boivin (1980) to conclude that rhönite + clinopyroxene began to crystallize at $1100-1150{ }^{\circ} \mathrm{C}$. However, temperatures for rhönite stability have independently also been estimated from homogenization and crystallization studies on rhönite-bearing melt inclusions in olivine or liquidustemperature determinations on the enclosing basaltic rock. Grapes et al. (2003) concluded that the assemblage rhönite + olivine + clinopyroxene + plagioclase in Mount Sidley xenoliths (Marie Byrd Land, West Antarctica) formed within a narrow temperature range of $1140-1190{ }^{\circ} \mathrm{C}$. Grapes and Keller (2010) inferred that $\mathrm{Fe}^{2+}$-dominant rhönite $\left(\mathrm{Mg}^{\#}<0.5\right.$; see Table 1) coexisting with subsilicic Al-Tibearing augite, olivine and titanian magnetite in tephrite and limburgite from the Kaiserstuhl volcanic complex, SW Germany, formed at temperatures of $1068-1137^{\circ} \mathrm{C}$. Sharygin et al. (2011) suggested that Mg-dominant rhönite in olivinehosted, silicate-melt inclusions in alkali basalt crystallized in the range of 1180 to $1260^{\circ} \mathrm{C}$. 
Some of the above estimates exceed the temperatures suggested by the work of Kunzmann (1989) in Fig. 10, and the $\mathrm{TiO}_{2}$ content of rhönite may play a role. In their study, Sharygin et al. (2011) cite quite variable $\mathrm{TiO}_{2}$ contents, between $8.1 \mathrm{wt} \%$ and $12.4 \mathrm{wt} \% \mathrm{TiO}_{2}$, without correlating their relatively high estimated temperatures directly with $\mathrm{TiO}_{2}$ contents. Kóthay et al. (2003) indicated in an abstract that $\mathrm{TiO}_{2}$-rich rhönite in alkali basalt from the Bakony-Balaton Highland and the Nógrád-Gömör volcanic fields, Pannonian Basin, Hungary, can be stable up to temperatures as high as $1220-1270^{\circ} \mathrm{C}$. Although Kóthay et al. (2003) did not give any explicit information on $\mathrm{TiO}_{2}$ contents, Sharygin et al. (2011) reported that rhönite from the same locality contains $\mathrm{TiO}_{2}$ in the range of $9.0 \mathrm{wt} \%-11.63 \mathrm{wt} \%$. $\mathrm{TiO}_{2}$ contents in Changle rhönite range from $10.5 \mathrm{wt} \%$ to $12.7 \mathrm{wt} \%$ (Table 1) and are therefore as high or even higher than those reported by Sharygin et al. (2011). They are also similar to and in part higher than in rhönite $(10.7 \mathrm{wt} \%-11.8 \mathrm{wt} \%)$ from the islands of Bravo and Fogu, Cabo Verde archipelago (Kogarko et al., 2005), and significantly higher than in the Kaiserstuhl volcanic complex ( $8 \mathrm{wt} \%-10 \mathrm{wt} \%$; Grapes and Keller, 2010). In particular, rhönite in sample SS17 and some in EGS03 contains very high amounts of $\mathrm{TiO}_{2}$ up to $12.5 \mathrm{wt} \%$.

\subsection{Comparison of REE patterns between rhönite and kaersutitic amphibole}

The composition of the rhönite-bearing basalt of the current study is similar to the weakly alkali basalt of Zeng et al. (2010) that belongs to the generation of old Changle basalts (24.0-10.3 Ma) and that is derived from asthenospheric mantle melts. Thus, in addition to the REE patterns of Changle rhönite from this study, the range of weakly alkali basalt compositions from Zeng et al. (2010) is shown in Fig. 8 for comparison as well. Additional patterns presented in Fig. 8 are from kaersutitic amphibole megacrysts in various types of alkalic basalt such as basanite, olivine nephelinite, transitional alkali-olivine basalt and hawaiite (Irving and Frey, 1984) and from kaersutite of Cenozoic basalt from the South China Sea (Yan et al., 2015).

Note that some of the REE patterns of Changle rhönite are very similar to the patterns of mantle amphiboles such as kaersutitic amphibole megacrysts or kaersutite in basalt (Irving and Frey, 1984; Yan et al., 2015; Fig. 8). Especially the REE patterns of euhedral rhönite in sample CL04 which show a maximum at $\mathrm{Nd}$ (Fig. 7b) are similar to kaersutitic amphibole megacrysts in basalts, in which only the relative amounts of all the REEs are moderately higher (Irving and Frey, 1984). These results imply that rhönite exhibits a geochemical fractionation behaviour of certain trace or REE elements similar to that of kaersutite or kaersutitic amphibole.

Overall, the REEs of rhönite in samples SS17 and CL04 are more depleted than those of kaersutite from the South China Sea (Yan et al., 2015; Fig. 8 - SCS) and kaersutitic amphibole megacrysts (Irving and Frey, 1984; Fig. 8).
Rhönite from samples EGS03 and CL01 is slightly depleted in MREEs (middle rare-earth elements) compared to kaersutite from the South China Sea and kaersutitic amphibole megacrysts (Yan et al., 2015; Irving and Frey, 1984; Fig. 8). The shape of the REE patterns of rhönite from samples CL01 and EGSO3 is similar to that of OIB (Sun and McDonough, 1989; Fig. 7a, c) and the Changle weakly alkali basalt of Zeng et al. (2010) (Fig. 8), although the amounts are slightly lower and rhönite from these two samples shows a marked enrichment of Lu. This phenomenon could also be the result of increasing alkalinity of the melt during the process of magma differentiation, which would lead to an enrichment of light REEs and some other elements such as $\mathrm{Lu}$ and $\mathrm{Nb}$ (Table 2). Thus not only the petrographical but also the REE features indicate that rhönite in samples EGS03 and CL01 crystallized as a late phase and perhaps contemporaneously with increasing alkalinity of the host magma.

\subsection{Chemical fingerprints of Changle rhönite with reference to amphibole}

By studying suprasubduction and intraplate metasomatic signatures, Coltorti et al. (2007b) concluded that mantle amphiboles are an important indicator that can mirror diverse geochemical characteristics; they thus contribute significantly to a better understanding of the respective geotectonic setting. Coltorti et al. (2007b) distinguished two types of amphibole from mantle xenoliths in basalt, an intraplate type (Iamphibole) and a suprasubduction type (S-amphibole). Geochemical signatures of I-amphibole were shown to be clearly different from those of S-amphibole due to their higher $\mathrm{Nb}$, $\mathrm{Ta}, \mathrm{Zr}$, Hf and Ti contents (Coltorti et al., 2007b). By comparing the chemical signatures of rhönite with those of amphibole, it appears possible to derive important petrological and geochemical fingerprints typical for a particular setting or particular melts that originate from the subduction of oceanic crust.

Recently, Dai et al. (2016), Li et al. (2017) and Xu et al. (2017) suggested that the sources of the OIB-like Cenozoic alkali basalts in the North China Craton (such as those from Shandong Peninsula) had experienced a "metasomatizing reaction" between the asthenospheric peridotite with melts derived from deeply subducted oceanic crust. The subducting slab stagnating in the mantle transition zone became a source of melts that carbonated-metasomatized the overlying mantle wedge peridotite ( $\mathrm{Li}$ and Wang, 2018; Xu et al., 2018). Rhönite-bearing Cenozoic alkali basalts from the Changle area are reported to represent typical intracontinental basalts (Zou et al., 2000; Xu et al., 2005; Tang et al., 2006; Liu et al., 2008a; Chen et al., 2009), and they are tectonically located above the old subduction zone, where the westward subduction of the Pacific slab occurred (Xu et al., 2017, 2018; Li and Wang, 2018). In essence, the Changle rhönitebearing basalts are derived from melts originating in an intracontinental setting where a reaction of the asthenospheric 


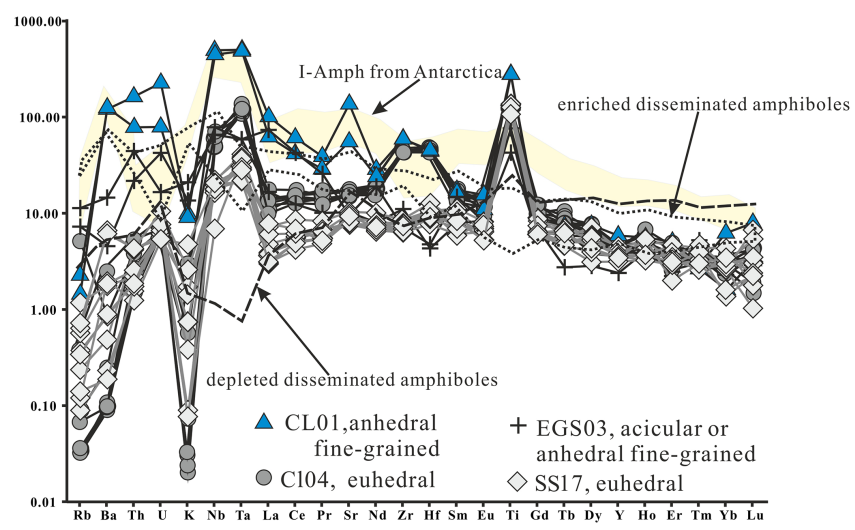

Figure 11. Chondrite-normalized (Sun and McDonough, 1989) incompatible-element spidergram for Changle rhönite. Depleted disseminated amphibole and enriched disseminated amphibole are from the basalt of Kapfenstein, Austria (Coltorti et al., 2007a), and I-Amph (I-amphibole) is from xenoliths from Antarctica (Coltorti et al., 2004, 2007a).

peridotite with melts that derived from subducted oceanic crust occurred.

As discussed above, REE patterns of Changle rhönite are similar to those of kaersutite in Cenozoic basalt (Yan et al., 2015) and kaersutitic amphibole megacrysts in basalt (Irving and Frey, 1984; Fig. 8). Although Changle rhönite does not represent a direct breakdown product of a former amphibole, the geochemical similarity between rhönite and amphibole suggests that rhönite could be able to take over the role of the petrogenetic indicator mineral amphibole by incorporating appropriate typical elements in a similar way. Indeed, the REE patterns of most rhönites resemble those of kaersutitic amphiboles or kaersutites in basalt (Yan et al., 2015; Irving and Frey, 1984; Fig. 8) and can signal suprasubduction and intraplate metasomatic mantle signatures (Coltorti et al., 2004, 2007b). The metasomatic mantle amphibole chosen for comparison originates from xenoliths of peridotite and lherzolite in basalt from Austria and Antarctica (Coltorti et al., 2004, 2007a, b). Note that the geochemical data of disseminated amphibole in lherzolite xenoliths in basalt from Kapfenstein, Austria, show subduction-related and intraplate metasomatic features (Coltorti et al., 2007a). Note also that LREEs and some incompatible elements of these amphiboles are similar to those of Changle rhönite from sample SS17, which also forms disseminated crystals in xenoliths (Fig. 11).

In a chondrite-normalized spidergram (Fig. 11), the Changle rhönite shows complex geochemical characteristics, revealing a distinct negative $\mathrm{K}$ anomaly and positive anomalies of Ta and Ti. Incompatible elements of Changle rhönite show (Fig. 11) that the behaviour of $\mathrm{Rb}, \mathrm{Ba}, \mathrm{Ta}$ and most REE (except Ho and $\mathrm{Lu}$ ) is similar to that in I-amphibole from xenoliths from Antarctica (Coltorti et al., 2004, 2007b). However, most incompatible elements of Changle rhönite (apart from Ti) are more strongly depleted than those of I- amphibole (Fig. 11). Depleted disseminated amphibole from Kapfenstein yields a similar trend in $\mathrm{Th}, \mathrm{U}, \mathrm{Eu}, \mathrm{Ti}, \mathrm{Gd}$ and some HREEs (Coltorti et al., 2007b) to most Changle rhönites, which are, however, slightly depleted in these elements (Fig. 11). On the other hand, most Changle rhönites show a trend with respect to $\mathrm{Sr}$ and $\mathrm{Ho}$ to $\mathrm{Lu}$ that is similar to the enriched amphibole from the Kapfenstein locality (Fig. 11).

Importantly, Coltorti et al. (2007b) have shown that $\mathrm{Nb}$ is the best discriminator element for distinguishing suprasubduction zone and intraplate settings. I-amphibole domains have relatively high amounts of $\mathrm{Nb}$ within a rather restricted range of about 10-1000 ppm compared to S-amphibole domains, where $\mathrm{Nb}$ is generally (with very little overlap) below $10 \mathrm{ppm}$. Assuming that the geochemical behaviour of these elements in amphibole is similar to that in rhönite, we see that although the four studied samples from Changle are located close to each other and also belong to the same geological formation (Yaoshan), they show clear distinguishing features. Whereas rhönite from sample SS17 contains $1.75-5.31 \mathrm{ppm} \mathrm{Nb}$ and thus indicates an S-type "amphibole" character, rhönites from the other samples, CL01, CL04 and EGS03, contain distinctively higher amounts of $\mathrm{Nb}$ (11.96$29.18 \mathrm{ppm}$ ) and point to an I-type character (Fig. 12a). Note that there is also a clear difference in $\mathrm{Nb}$ content between samples CL01, CL04 and EGS03; they form distinctive groups.

According to McDonough and Sun (1995), a chondritic character is indicated by $\mathrm{Ti} / \mathrm{Nb}_{\mathrm{ch}}=1823$ and $\mathrm{Zr} / \mathrm{Nb}_{\mathrm{ch}}=15.7$, where $\mathrm{Ti} / \mathrm{Nb}>1823$ and $\mathrm{Zr} / \mathrm{Nb}>15.7$, $\mathrm{Ti} / \mathrm{Nb}<1823$ and $\mathrm{Zr} / \mathrm{Nb}<15.7$, respectively, indicate a suprachondritic or subchondritic character (Coltorti et al., 2007b). In addition, Coltorti et al. (2007b) showed that $\mathrm{Ti} / \mathrm{Nb}$ and $\mathrm{Zr} / \mathrm{Nb}$ ratios of amphibole can be used to distinguish between S-amphibole, which is chondritic to slightly suprachondritic, and I-amphibole, which yields a subchondritic character (Fig. 12b). With respect to rhönite from Changle, Ti/Nb ratios of rhönite from samples SS17 and CL04 are much higher than 1823 and would thus indicate a typical suprachondritic character, whereas rhönite from samples EGS03 and CL01 would indicate a subchondritic character (Fig. 12b; Table 2). However, with regard to $\mathrm{Zr} / \mathrm{Nb}$ ratios, most of the Changle rhönites are subchondritic, and only one rhönite crystal in the xenolith from sample SS17 yields higher values than 15.5 and is thus suprachondritic (McDonough and Sun, 1995) (range of 1.65-17.63; Table 2).

In the $\mathrm{Zr}-\mathrm{Nb}$ diagram (Fig. 12a), all rhönites from sample SS17 are located in the S-amphibole field, whereas rhönite from samples CL01 and EGS03 (with one outlier) plots in the I-amphibole field; all rhönites from sample $\mathrm{Cl0} 4$ plot in between. In the diagram of $\mathrm{Zr} / \mathrm{Nb}$ versus $\mathrm{Ti} / \mathrm{Nb}$ (Fig. 12b), rhönite from samples SS17 and CL04 falls into or close to the S-amphibole field, whereas rhönite from samples CL01 and EGS03 is located outside but close to the I-amphibole field. 

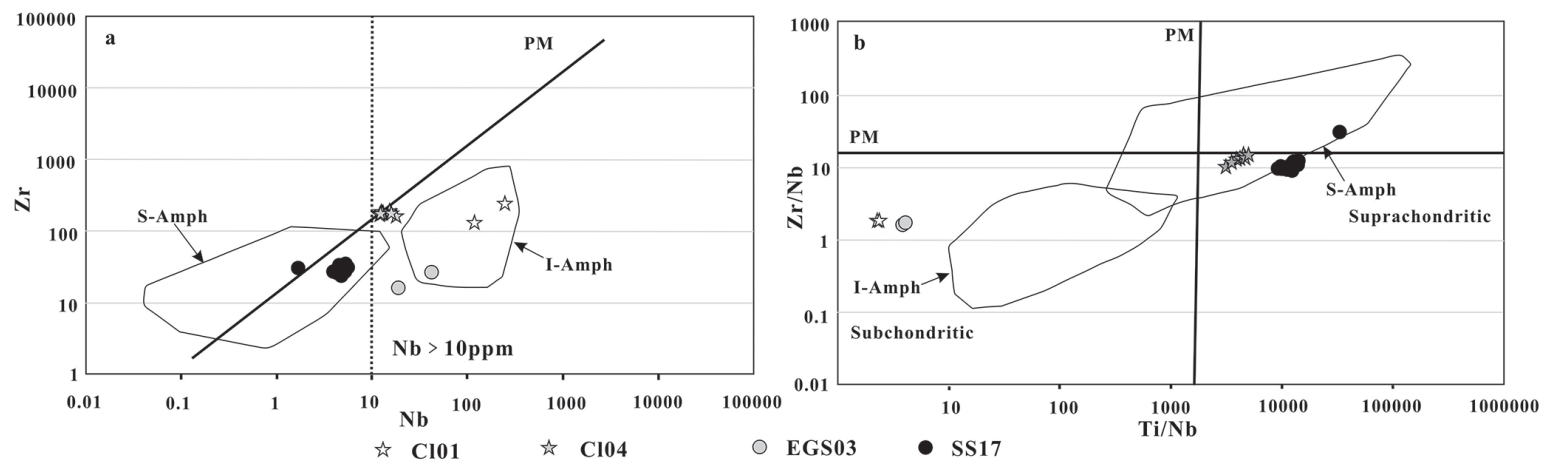

Figure 12. Diagrams of $\mathrm{Zr}$ versus $\mathrm{Nb}$ and $\mathrm{Zr} / \mathrm{Nb}$ versus $\mathrm{Ti} / \mathrm{Nb}$ of Changle rhönite modified after Coltorti et al. (2007b); PM is primordial mantle.

According to Coltorti et al. (2007b), amphiboles straddling the I- and S-amphibole fields possibly indicate a suprasubduction to intraplate transition stage. Assuming that such data on amphibole are transferable to rhönite, those which document an overlap of I and S character may have experienced an intraplate metasomatic event overprinted by a subduction-related metasomatic episode. Indeed, with respect to the local geological environment of the rhönitebearing Changle intraplate alkali basalt, there is petrological and geochemical evidence of an old Pacific subduction event and further Cenozoic intraplate metasomatism.

Note that Ionov and Hofmann (1995) hypothesized that the amphibole-melt partition coefficient for $\mathrm{Nb}$ is lower than that for Ta during mantle metasomatism, based on their study of disseminated and vein-related amphibole separated from mantle xenoliths in alkali basalt (Ionov and Hofmann, 1995). As a consequence of progressively increasing $\mathrm{Nb} / \mathrm{Ta}$ ratios in the residual melt resulting from the precipitation of amphibole, earlier-formed, vein-related amphibole has a lower $\mathrm{Nb} / \mathrm{Ta}$ ratio than disseminated amphibole of a later generation (Ionov and Hofmann, 1995). As a characteristic feature of the Changle rhönite, the $\mathrm{Nb} / \mathrm{Ta}$ ratio of euhedral crystals from sample CL04 is in general quite low (7.2-10.3), whereas the range of ratios of the anhedral crystals from the acicular type CL01 is distinguishably higher and between 16.3 and 17.3 (Table 2; Fig. 2b, c, e, f). The $\mathrm{Nb} / \mathrm{Ta}$ ratio of euhedral grains from sample SS17 varies widely between 3.3 and 15.9 and reaches the highest values in fine-grained rhönite from sample EGS03 (19.6-23.6) (Table 2; Fig. 3b, c, e, f). On average, these differences can help to indicate possible growth sequences. In conjunction with the petrographical features, we propose that the larger euhedral rhönite crystals formed earlier than the anhedral smaller ones.

\section{Conclusions}

Mineralogical, petrographical and geochemical characteristics of rhönite from three alkali-olivine basalts and one xenolith in basalt from Changle show that rhönite grew at differ- ent stages due to different reactions and formation conditions but generally formed at temperatures exceeding $950^{\circ} \mathrm{C}$ and pressures below $0.5 \mathrm{kbar}$.

Euhedral rhönite from samples SS17 and CL04 is proposed to have crystallized earlier than the acicular and anhedral grains in samples EGS03 and CL01.

Rhönite is documented to have a wide range of compositions in major oxides; the main substitutions derived are

$$
\begin{aligned}
& \text { 1. } \mathrm{Si}^{4+}+\mathrm{Na}^{+}=(\mathrm{Al}, \mathrm{Fe})^{3+}+\mathrm{Ca}^{2+} \text {, } \\
& \text { 2. } \mathrm{Mg}^{2+}=(\mathrm{Fe}, \mathrm{Mn})^{2+} \text { and } \\
& \text { 3. } \mathrm{Ti}^{4+}+(\mathrm{Mg}+\mathrm{Fe}+\mathrm{Mn})^{2+}=2 \mathrm{Fe}^{3+} \text {. }
\end{aligned}
$$

Besides providing important local insights into the formation mechanisms of rhönite from the Changle alkali-basalt occurrences, the important objectives of the current paper are to present REE and trace-element data for different rhönite generations as well as a compilation of crystal-chemistry characteristics which may serve as fundamental information on rhönite-bearing rocks in general. Since rhönite and amphibole have structural similarities and also share geochemical characteristics, we anticipate that with future studies of the REE characteristics of amphibole and rhönite from other localities, a more precise "geochemical link" between these minerals can be established, and rhönite may become an important indicator for discriminating different geotectonic settings.

Data availability. All data derived from this research are presented in the enclosed text, tables and figures.

Author contributions. L-QZ and X-HL carried out trace elements of rhönite, F-MK carried out major elements of rhönite and wrote the first draft, H-PS and X-PL contributed to the experimental strategy, interpretations, discussion and manuscript revision. 
Competing interests. The authors declare that they have no conflict of interest.

Special issue statement. This article is part of the special issue "To Christian Chopin, in recognition of 30 years of dedicated service to EJM". It is not associated with a conference.

Acknowledgements. We thank Thomas Kunzmann and other two anonymous reviewers for their thoughtful and constructive comments on the paper and chief editor Patrick Cordier for his editorial handling. Our special thanks go to guest editor Walter Maresch for his patience, constructive criticism and fruitful suggestions.

Financial support. This research has been supported by the Natural Science Foundation of Shandong Province, China (grant no. ZR2016DM04), Key Project of Natural Science Foundation of China (grant no. 41230960), "Chinese large-very large deposit, geodynamic, and quantitative evaluation of the comprehensive study process" (grant no. 1212011220928), and the Scientific Research Foundation of Shandong University of Science and Technology for Recruited Talents (grant no. 2014RCJJ009).

Review statement. This paper was edited by Walter Maresch.

\section{References}

Anan'ev, V. V. and Selyangin, O. B.: Rhonite in molten inclusions from the olivine of Allivalite Nodules from Malyi Semyachik volcano and basalts of Klyuchevskoi volcano, Kamchatka, J. Volcanol. Seismol., 5, 335-340, https://doi.org/10.1134/S0742046311050022, 2011.

Boivin, P.: Données expérimentales préliminaires sur la stabilité de la rhönite é 1 atmosphére. Application aux gisements naturels, Bull. Minér., 103, 491-502, https://doi.org/10.3406/bulmi.1980.7411, 1980.

Bonaccorsi, E., Merlino, S., and Pasero, M.: Rhönite: structural and microstructural features, crystal chemistry and polysomatic relationships, Eur. J. Mineral., 2, 203-218, https://doi.org/10.1127/ejm/2/2/0203, 1990.

Brögger, W. C.: Mineralien der südnorweg. Augitsyenite. 50. Aenigmatit, Breithaupt (Kölbingit, Breithaupt), Z. Krystallogr. Mineral., 16, 423-433, 1890.

Chen, L., Zheng, T., and Xu, W.: A thinned lithospheric image of the Tanlu Fault Zone, eastern China: Constructed from wave equation based receiver function migration, J. Geophys. Res., 111, B09312, https://doi.org/10.1029/2005JB003974, 2006.

Chen, L.-H., Zeng, G., Jiang, S.-Y., Hofmann, A. W., Xu, X.-S., and Pan, M.-B.: Sources of Anfengshan basalts: subducted lower crust in the Sulu UHP belt, China, Earth Planet. Sci. Lett., 286, 426-435, https://doi.org/10.1016/j.eps1.2009.07.006, 2009.
Coltorti, M., Beccaluva, L., Bonadiman, C., Faccini, B., Ntaflos, T., and Siena, F.: Amphibole genesis via metasomatic reaction with clinopyroxene in mantle xenoliths from Victoria Land, Antarctica, Lithos, 75, 115-139, https://doi.org/10.1016/j.lithos.2003.12.021, 2004.

Coltorti, M., Bonadiman, C., Faccini, B., Ntaflos, T., and Siena, F.: Slab melt and intraplate metasomatism in Kapfenstein mantle xenoliths (Styria Basin, Austria, in: Melting, Metasomatism and Metamorphic Evolution in the Lithospheric Mantel, edited by: Coltorti, M., Downes, H., and Piccardo, G. B., Lithos. Special Issue, 94, 66-89, https://doi.org/10.1016/j.lithos.2006.07.003, 2007a.

Coltorti, M., Bonadiman, C., Faccini, B., Gregoire, M., O’Reilly, S. Y., and Powell, W.: Amphiboles from suprasubduction and intraplate lithospheric mantle, Lithos, 99, 68-84, https://doi.org/10.1016/j.lithos.2007.05.009, 2007b.

Coltorti, M., Bonadiman, C., O'Reilly, S. Y., Griffin, W. L., and Pearson, N. J.: Buoyant ancient continental mantle embedded in oceanic lithosphere (Sal Island, Cape Verde Archipelago), Lithos., 120, 223-233, https://doi.org/10.1016/j.lithos.2009.11.005, 2010.

Dai, L.-Q., Zheng, Y.-F., and Zhao, Z.-F.: Termination time of peak decratonization in North China: geochemical evidence from mafic igneous rocks, Lithos., 240-243, 327-336, https://doi.org/10.1016/j.lithos.2015.11.014, 2016.

Dasgupta, R., Jackson, M. G., and Lee, C. T.: Major element chemistry of ocean island basalts-conditions of mantle melting and heterogeneity of mantle source, Earth Planet. Sci. Lett., 289, 377-392, https://doi.org/10.1016/j.eps1.2009.11.027, 2010.

Deer, W. A., Howie, R. A., and Zussman, J. (Eds.): Rock-Forming Minerals, Vol. 2a, Single Chain Silicates, Wiley, New York, Americian, 1978.

Doroozi, R., Vaccaro, C., and Masoudi, F.: Rhönite in undersaturated alkaline gabbroic rocks, Central Alborz, North Iran: petrography and mineral chemistry, Arab. J. Geosc., 9, 665, https://doi.org/10.1007/s12517-016-2684-3, 2016.

Fan, W. M., Zhang, H. F., Baker, J., Jarvis, K. E., Mason, P. R. D., and Menzies, M. A.: On and off the North China Craton: where is the Archaean keel?, J. Petrol, 41, 933-950, https://doi.org/10.1093/petrology/41.7.933, 2000.

Galuskina, I. O., Galuskin, E. V., Pakhomova, A. S., Widmer, R., Armbruster, T., Krüger, B., Grew, E. S., Vapnik, Y., Dzierażanowski, P., and Murshko, M.: Khesinite, $\mathrm{Ca}_{4} \mathrm{Mg}_{2} \mathrm{Fe}_{10}^{3+} \mathrm{O}_{4}\left[\left(\mathrm{Fe}_{10}^{3+} \mathrm{Si}_{2}\right) \mathrm{O}_{36}\right]$, a new rhönite-group (sapphirine supergroup) mineral from the Negev Desert, Israel - natural analogue of the SFCA phase, Eur. J. Mineral., 29, 101-116, https://doi.org/10.1127/ejm/2017/0029-2589, 2017.

Grapes, R. and Keller, J.: $\mathrm{Fe}^{2+}$-dominant rhönite in undersaturated alkaline basaltic rocks, Kaiserstuhl volcanic complex, Upper Rhine Graben, SW Germany, Eur. J. Mineral., 22, 285-292, https://doi.org/10.1007/s12517-016-2684-3, 2010.

Grapes, R. H., Wysoczanski, R. J., and Hoskin, P. W. O.: Rhönite paragenesis in pyroxenite xenoliths, Mount Sidley volcano, Marie Byrd Land, West Antarctica, Mineral. Mag., 67, 639-651, https://doi.org/10.1180/0026461036740123, 2003.

Grew, E. S., Hålenius, U., Pasero, M., and Barbier, J.: Recommended nomenclature for the sapphrine and surinamite groups (sapphirine supergroup), Mineral. Mag., 72, 839-876, https://doi.org/10.1180/minmag.2008.072.4.839, 2008. 
Grützner, T., Prelević, D., and Akal, C.: Geochemistry and origin of ultramafic enclaves and their basanitic host rock from Kula Volcano, Turkey, Lithos, 180-181, 58-73, https://doi.org/10.1016/j.lithos.2013.08.001, 2013.

He, H.-Y., Deng, C.-L., Pan Y.-X., Deng, T., Luo Z.-H., Sun, J.-M., and Zhu, R-X.: New ${ }^{40} \mathrm{Ar} /{ }^{39} \mathrm{Ar}$ dating results from the Shanwang Basin, eastern China: Constraints on the age of the Shanwang Formation and associated biota, Phys. Earth Planet. In., 187, 6675, https://doi.org/10.1016/j.pepi.2011.05.002, 2011a.

He, H.-Y., Zhu, R.-X., and Saxton, J.: Noble gas isotopes in corundum and peridotite xenoliths from the eastern North China Craton: Implication for comprehensive refertilization of lithospheric mantle, Phys. Earth Planet. In., 189, 185-191, https://doi.org/10.1016/j.pepi.2011.09.001, 2011b.

Hofmann, A. W. and White, W. M.: Mantle plumes from ancient oceanic crust, Earth Planet. Sci. Lett., 57, 421-436, https://doi.org/10.1016/0012-821X(82)90161-3, 1982.

Hu, W.-X., Song, Y.-C., Chen, X.-M., Tao, M.-X., and Zhang, L.P.: Noble gases in corundum megacrysts from the basalts in Changle, Shandong Province, eastern China, Chinese Sci. Bull., 52, 380-387, https://doi.org/10.1007/s11434-007-0044-0, 2007.

Huckenholz, H., Kunzmann, T., and Spicker, C.: Stability of titanian magnesio-hastingsite and its breakdown to rhönite bearing assemblages, Terra Cognita., 8, p. 11, 1988.

Ionov, D. A. and Hofmann, A. W.: Nb-Ta-rich mantle amphiboles and micas: implications for subduction-related metasomatic trace element fractionations, Earth Planet. Sci. Lett., 131, 341356, https://doi.org/10.1016/0012-821X(95)00037-D, 1995.

Irving, A. J. and Frey, F. A.: Trace element abundances in megacrysts and their host basalts: constraints on partition coefficients and megacryst genesis, Geochim. Cosmochim. Acta, 48, 1201-1221, https://doi.org/10.1016/0016-7037(84)90056-5, 1984.

Johnston, A. D. and Stout, J. H.: A highly oxidized ferrian salite-, kennedyite-, forsterite-, and rhönite-bearing alkali gabbro from Kauai, Hawaii and its mantle xenoliths, Am. Mineral., 69, 57-68, 1984.

Johnston, A. D. and Stout, J. H.: Compositional variation of naturally occurring rhoenite, Am. Mineral, 70, 1211-1216, 1985.

Kogarko, L. N., Hellebrand, E., and Ryabchikov, I. D.: Trace Element Partitioning between Rhönite and Silicate Melt in Cape Verde Volcanics, Geochem. Int., 43, 3-9, 2005.

Kong, F. M., Li, X. P., Wu, S., Li, S. J., and Xu, Y. M.: Petrography, mineralogy and the evolution of peridotites from the Dongdegou, southwestern Tianshan and its geological significance, Acta Petrotol. Sin. (in chinese with English abstract), 29, 723-738, 2013.

Kong, F. M., Liu, X., Li, X. P., Guo, J. H., and Zhao, G. C.: Mineralogical and petrogeochemical characteristics of ultramafic rocks from the metamorphic basement of the Jiaobei terrane, Acta Petrotol. Sin. (in Chinese with English abstract), 31, 1549-1563, 2015.

Kong, F. M., Li, X. P., Zhao, L. Q., and Chen, S.: Petrography and Mineral Chemistry of Corundum and Spinel Menocryst in the Cenozoic Basalt at Changle, Shandong Prinvice, Geol. Rev. (in Chinese with English abstract), 63, 441-457, 2017.

Kóthay, K., Peto, M., Sharygin, V. V., Torok, K., and Szabo, C.: Silicate melt inclusions in olivine phenocrysts from Hegyestu (Bakony-Balaton Highland) and Pecsko alkaline basalts (Nograd-Gomor), Hungary, in: EGS - AGU - EUG Joint Assembly, Nice, France, 6-11 April 2003, abstract id. 748, 2003.

Kretz, R.: Symbols for rock-forming minerals, Am. Mineral., 68, 277-279, https://doi.org/10.1016/0040-1951(84)90122-7, 1983.

Kunzmann, T.: Rhönit: Mineralchemie, Paragenese und Stabilität in alkalibasaltischen Vulkaniten, Ein Beitrag zur Minerogenese der Rhönit-Änigmatit-Mischkristallgruppe, $\mathrm{PhD}$ thesis, Ludwig-Maximillians University, Munich, p. 151, 1989.

Kunzmann, T.: The aenigmatite-rhönite mineral group, Eur. J. Mineral., 11, 743-756, https://doi.org/10.1127/ejm/11/4/0743, 1999.

Li, S. G. and Wang, Y.: Formation time of the big mantle wedge beneath eastern China and a new lithospheric thinning mechanism of the North China craton-Geodynamic effects of deep recycled carbon, Sci. China Earth Sci., 61, 853-868, https://doi.org/10.1007/s11430-017-9217-7, 2018.

Li, S.-G., Yang, W., Ke, S., Meng, X., Tian, H., Xu, L., He, Y., Huang, J., Wang, X.-Z., Xia, Q.-K., Sun, W., Yang, X., Ren, Z.-Y., Wei, H., Liu, Y., Meng, F., and Yan, J.: Deep carbon cycles constrained by a large-scale mantle $\mathrm{Mg}$ isotope anomaly in eastern China, Natl. Sci. Rev., 4, 111-120, https://doi.org/10.1093/nsr/nww070, 2017.

Liu, D.-Y., Nutman, A. P., Compston, W., Wu, J.-S., and Shen, Q.H.: Remnants of 3800Ma crust in the Chinese part of the SinoKorean Craton, Geology, 20, 1-20, https://doi.org/10.1130/00917613(1992)020<0339:ROMCIT>2.3.CO;2, 1992.

Liu, Y., Gao, S., Hu, Z., Gao, C., Zong, K., and Wang, D.: Continental and oceanic crust recycling-induced melt-peridotite interactions in the Trans-North China Orogen: U-Pb dating, Hf isotopes and trace elements in zircons from mantle xenoliths, J. Petrol., 51, 537-571, https://doi.org/10.1093/petrology/egp082, 2010.

Liu, Y.-S., Gao, S., Kelemen, P. B., and Xu, W.-L.: Recycled crust controls contrasting source compositions of Mesozoic and Cenozoic basalts in the North China Craton, Geochim. Cosmochim. Acta, 72, 2349-2376, https://doi.org/10.1016/j.gca.2008.02.018, 2008a.

Liu, Y.-S., Hu, Z.-C., Gao, S., Günther, D., Xu, J., Gao, C.G., and Chen, H.-H.: In situ analysis of major and trace elements of anhydrous minerals by LA-ICP-MS without applying an internal standard, Chem. Geol., 257, 34-43, https://doi.org/10.1016/j.chemgeo.2008.08.004, 2008b.

Luo, D., Chen, L.-H., and Zeng, G.: Gensis of intra-continental strongly alkaline volcanic rocks: a case study of Dashan nephelinites in Wudi, Shandong Province, North China, Acta Petrol. Sin. (in Chinese with English abstract), 25, 311-319, https://doi.org/10.2307/2202054, 2009.

McDonough, W. F. and Sun, S. S.: The composition of Earth, Chem. Geol., 120, 223-253, https://doi.org/10.1016/00092541(94)00140-4, 1995.

Meng, F.-C., Safonova, I., Chen, S.-S., Liu, J.-Q., and Rioual, P.: Late Cenozoic intra-plate basalts of the Greater Khingan Range in NE China and Khangai Province in Central Mongolia, Gondwana Res., 63, 65-84, https://doi.org/10.1016/j.gr.2018.05.009, 2018.

Nédli, Z. and Tóth, T. M.: Petrography and mineral chemistry of Rhönite in ocelli of alkali basalt from villany mts, SW Hungary, Acta Mineral.-Petrogr., 44, 51-56, 2003.

Niu, Y.-L. and O'Hara, M. J.: Origin of ocean island basalts: a new perspective from petrology, geochemistry, and mineral 
physics considerations, J. Geophys. Res.-Planet., 108, 22092228, https://doi.org/10.1029/2002JB002048, 2003.

Palache, C.: Crystallographic notes on anapaite, ainigmatite and eudidymite, Z. Kristallogr.-Cryst. Mater., 86, 280-291, https://doi.org/10.1524/zkri.1933.86.1.280, 1933.

Peretyazhko, I. S., Savina, E. A., and Khrîmova, E. A.: Minerals of the rhönite-kuratite series in paralavas from a new combustion metamorphic complex in the choirNyalga basin (Central Mongolia): composition, mineral assemblages and formation conditions, Mineral. Mag., 81, 949-974, https://doi.org/10.1180/minmag.2016.080.144, 2017.

Pilet, S., Baker, M. B., and Stolper, E. M.: Metasomatized lithosphere and the origin of alkaline lavas, Science, 320, 916-919, https://doi.org/10.1126/science.1156563, 2008.

Ramalho, R., Helffrich, G., Schmidt, D. N., and Vance, D.: Tracers of uplift and subsidence in the Cape Verde archipelago, J. Geol. Soc., London, 167, 519-538, https://doi.org/10.1144/001676492009-056, 2010.

Sharygin, V. V., Kóthay, K., Szabó, C. S., Timina, T. J., Török, K., Vapnik, Y., and Kuzmin, D. V.: Rhönite in alkali basalts: silicate melt inclusions in olivine phenocrysts, Russ. Geol. Geophys., 52, 1334-1352, https://doi.org/10.1016/j.rgg.2011.10.006, 2011.

Shchipalkina, N. V., Pekov, V., Chukanov, N. V., Koshlyakova, N. N., Ternes, B., and Schuller, W.: Crystal chemistry of dorrite from the Eifel volcanic region, Germany, and chemical variations in the khesinite-dorrite-rhönite-kuratite solid-solution system, Miner. Petrol., 113, 249-259, https://doi.org/10.1007/s00710018-0645-0, 2019.

Su, F., Xiao, Y., He, H.-Y., Su, B.-X., Wang, Y., and Zhu, R.-X.: $\mathrm{He}$ and $\mathrm{Ar}$ isotope geochemistry of pyroxene megacrysts and mantle xenoliths in Cenozoic basalt from the Changle-Linqu area in western Shandong, Chinese Sci. Bull., 59, 396-411, https://doi.org/10.1007/s11434-013-0027-2, 2014.

Sun, S. S. and McDonough, W. F.: Chemical and isotopic systematic of oceanic basalt: implication for mantle composition and process, in: Magmatism in Oceanic Basins, edited by: Saunders, A. D. and Norry, M. J., Geol. Soc. Spec. Publ. Lond., London, 42, 313-345, 1989.

Tang, Y.-J., Zhang, H.-F., and Ying, J.-F.: Asthenospherelithospheric mantle interaction in an extensional regime: implication from the geochemistry of Cenozoic basalts from Taihang Mountains, North China Craton, Chem. Geol., 233, 309-327, https://doi.org/10.1016/j.chemgeo.2006.03.013, 2006.

Treiman, A. H.: Rhönite in Luna 24 pyroxenes: First find from the Moon, and implications for volatiles in planetary magmas, Am. Mineral., 93, 488-491, https://doi.org/10.2138/am.2008.2781, 2008.

Vogelsang, K.: Beitráge zur Kenntnis der Trachyt- und Basaltgesteine der Hohen Eifel, Z. dt. Geol. Ges., 42, 1-57, 1890.

Walenta, K.: Zur Kristallographie des Rhönits, Z. Kristallogr., 130S, 14-230, https://doi.org/10.1524/zkri.1969.130.16.214, 1969.

White, R. W.: Ultramafic inclusions in basaltic rocks from Hawaii, Contrib. Mineral. Petrol., 12, 245-314, https://doi.org/10.1007/BF00518082, 1966.

Wilshire, H. G., Calk L. C., and Schwarzman, E. C.: Kaersutite - a product of reaction between pargasite and basanite at Dish Hill, California, Earth. Planet. Sci. Lett., 10, 281-284, https://doi.org/10.1016/0012-821X(71)90019-7, 1971.
Xiao, Y., Zhang, H.-F., Fan, W., Ying, J.-F., Zhang, J., Zhao, X.M., and Su, B.-X.: Evolution of lithospheric mantle beneath the Tan-Lu fault zone, eastern North China Craton: evidence from petrology and geochemistry of peridotite xenoliths, Lithos, 117, 229-246, https://doi.org/10.1016/j.lithos.2010.02.017, 2010.

Xiao, Y., Teng, F.-Z., Zhang, H.-F., and Yang, W.: Large magnesium isotope fractionation in peridotite xenoliths from eastern North China craton: Product of melt-rock interaction, Geochim. Cosmochim. Acta, 115, 241-261, https://doi.org/10.1016/j.gca.2013.04.011, 2013.

Xu, Y.-G., Chung, S.-L., Ma, J., and Shi, L.-B.: Contrasting Cenozoic lithospheric evolutionand architecture in the eastern and western Sino-Korean craton: Constraints from geochemistry of basalts and mantle xenoliths, J. Geol., 112, 593-605, https://doi.org/10.1086/422668, 2004.

Xu, Y.-G., Ma, J.-L, Frey, F. A., Feigenson, M. D., and Liu, J.F.: Role of lithosphere-asthenosphere interaction in the genesis of Quaternary alkali and tholeiitic basalts from Datong, western North China Craton, Chem. Geol., 224, 247-271, https://doi.org/10.1016/j.chemgeo.2005.08.004, 2005.

Xu, Y.-G., Zhang, H.-H., Qiu, H.-N., Ge, W.-C., and Wu, F.-Y.: Oceanic crust components in continental basalts from Shuangliao, Northeastern China: derived from the mantle transition zone? Chem. Geol., 328, 168-184, https://doi.org/10.1016/j.chemgeo.2012.01.027, 2012.

Xu, Y. G., Li, H. Y., Hong, L., Ma, L., Ma, Q., and Sun, M.: Generation of Cenozoic intraplate basalts in the big mantle wedge under eastern Asia, Sci. China Earth Sci., 61, 869-886, https://doi.org/10.1007/s11430-017-9192-y, 2018.

Xu, Z., Zheng, Y.-F., and Zhao, Z.-F.,: The origin of Cenozoic continental basalts in east-central China: Constrained by linking $\mathrm{Pb}$ isotopes to other geochemical variables, Lithos, 268-271, 302319, https://doi.org/10.1016/j.lithos.2016.11.006, 2017.

Yan, J., Li, X., Zhao, L., and Yan, Q.: Geochemistry of kaersutites in Cenozoic alkali basalts from the South China Sea, Geol. Rev. (in Chinese with English abstract), 61, 1034-1446, 2015.

Yu, S-Y., Xu, Y.-G., Zhou, S.-H., Lan, J.-B., Chen, L.-M., Shen, N.-P., Zhao, J.-X., and Feng, Y.-X.: Late Cenozoic basaltic lavas from the Changbaishan-Baoqing Volcanic Belt, NE China: Products of lithosphere-asthenosphere interaction induced by subduction of the Pacific plate, J. Asian Earth Sci., 164, 260-273, https://doi.org/10.1016/j.jseaes.2018.06.031, 2018

Yu, Y., Xu, X. S., and Chen, X. M.: Genesis of zircon megacrysts in Cenozoic alkali basalts and the heterogeneity of subcontinental lithospheric mantle, eastern China, Miner. Petrol., 100, 75-94, https://doi.org/10.1007/s00710-010-0120-z, 2010.

Zeng, G., Chen, L.-H., Xu, X.-S., Jiang, S.-Y., and Hofmann, A. W.: Carbonated mantle sources for Cenozoic intra-plate alkaline basalts in Shandong, North China, Chem. Geol., 273, 35-45, https://doi.org/10.1016/j.chemgeo.2010.02.009, 2010.

Zhang, J.-J., Zheng, Y.-F., and Zhao, Z.-F.: Geochemical evidence for interaction between oceanic crust and lithospheric mantle in the origin of Cenozoic continental basalts in east-central China, Lithos, 110, 305-326, https://doi.org/10.1016/j.lithos.2009.01.006, 2009.

Zhao, L., Kong, F., Li X., Chen, S., and Wang, W.: Metallogenic mechanism of corundum megacrysts in cenozoic alkaline basalt - a case investigation of changle,Western Shandong, Journal of 
Shandong University of Science and Technology (Natural Science) (in Chinese with English abstract), 34, 7-27, 2015.

Zheng, J., O'Reilly, S., Griffin, W., Lu, F., and Zhang, M.: Nature and evolution of Cenozoic lithospheric mantle beneath Shandong peninsula, Sino-Korean craton, Int. Geol. Rev., 40, 471-499, https://doi.org/10.1080/00206819809465220, 1998.
Zou, H.-B., Zindler, A., Xu, X.-S., and Qi, Q.: Major, trace element, and $\mathrm{Nd}, \mathrm{Sr}$ and $\mathrm{Pb}$ isotope studies of Cenozoic basalts in $\mathrm{SE}$ China: mantle sources, regional variations, and tectonic significance, Chem. Geol., 171, 33-47, https://doi.org/10.1016/S00092541(00)00243-6, 2000. 